\title{
Ivanec kao eksperimentalna lokacija jugoslavenske samoposlužne trgovine*
}

U članku su predstavljene okolnosti i početak razvoja koncepta samoposluživanja u socijalističkoj Jugoslaviji. Pitanje razvoja samoposluga stavlja se u kontekst ondašnjeg međunarodnog položaja Jugoslavije koja je u blokovski podijeljenom svijetu lavirala između Istoka i Zapada. Iako je razvoj samoposluživanja u jugoslavenskom kontekstu bio projekt osmišljen u državnome vrhu nakon 1957. godine, on je svoj početak imao ranije i vezan je za inicijativu nekih poduzetnih pojedinaca. Prva samoposluga u Jugoslaviji, ujedno i prva u Jugoistočnoj Europi, otvorena je 1956. godine u mjestu Ivancu pokraj Varaždina, a isto mjesto imalo je i prvu putujuću samoposlugu u Jugoslaviji. U radu se prikazuje kako je i u kojoj mjeri razvoj samoposluživanja utjecao na društveno-ekonomske promjene na lokalnoj razini, od sredine 1950-ih do početka 1970-ih. Rad se temelji na izvornoj arhivskoj građi, službenom glasilu poduzeća „Varaždinski magazin“, onodobnom tisku te relevantnoj recentnijoj literaturi.

\section{Uvod}

Koncept i samu ideju samoposluge sa sigurnošću možemo pripisati zapadnim, kapitalističkim ekonomskim sustavima. U razvoju samoposlužne trgovine gotovo do kraja 20. stoljeća primat su držale kapitalistički orijentirane zemlje, s time da je većina inovacija dolazila iz Sjedinjenih Američkih Država (SAD), odakle su se potom preslikavale u Zapadnoj Europi. ${ }^{1}$ U sklopu ekonomske historije, kao i historije svakodnevice, pojava samoposluga našla je svoje mjesto kako u velikim svjetskim, tako i u europskim historiografijama. U hrvatskoj, kao i u historiografijama država sljednica socijalističke Jugoslavije, tema razvoja samoposluživanja tek u novije vrijeme ulazi u fokus povjesničara. Najpoznatiji su primjeri historiografskog problematiziranja ideje samoposluge na prostoru bivše Jugoslavije knjige i članak Igora Dude te članak i knjiga Radine Vučetić. ${ }^{2}$ Novije sinteze

Ovaj rad sufinancirala je Hrvatska zaklada za znanost projektom 3481.

1 Kako Radina Vučetić tvrdi, razvoj potrošačkog društva u Europi povezuje se s amerikanizacijom europske ekonomije, no korijene treba tražiti u 18. i 19. stoljeću u Europi, a oni su neraskidivo vezani s poviješću europskoga kapitalizma i kulture. Ipak, preuzimanjem istog i prilagodbom uvjetima u SAD-u, ta država postaje svjetski lider u pitanjima potrošnje, a jedan od produkata bile su samoposluge. VUČETIĆ 2012b: 278.

2 DUDA 2005; Isti 2010; Isti 2003; VUČETIĆ 2012a; Ista 2012 b. 
hrvatske ili jugoslavenske povijesti rijetko sustavno obrađuju ekonomsku i povijest svakodnevice socijalističke Jugoslavije, tako da se ni pitanje samoposluga u njima ne spominje. ${ }^{3}$

Historiografski doprinos o prvoj jugoslavenskoj samoposluzi, otvorenoj 1956. godine u malome zagorskome mjestu Ivancu kraj Varaždina, uistinu je slab. Već spomenuti članci i knjige Igora Dude i Radine Vučetić Ivanec tek spominju, ali ne donose dublje analize slučaja. Detaljnije informacije o samoposluzi mogu se pronaći većinom u člancima Eduarda Kušena, ali ne radi se o historiografskoj, već prvenstveno turističkoj analizi. ${ }^{4}$ Ovaj će rad na osnovi izvorne arhivske građe, koja se čuva u Državnom arhivu u Varaždinu, podataka iz Katastra grada Ivanca te službenoga glasila poduzeća „Varaždinski magazin“ i onodobnog lokalnog i republičkog tiska proširiti i produbiti dosadašnje spoznaje problematike.

Glavni cilj ovog članka jest prikazati okolnosti koje su dovele do otvaranja prve samoposluge u Jugoslaviji, početke njezina djelovanja te utjecaj koji je razvoj samoposluživanja imao na društveno-ekonomsko stanje u lokalnoj sredini, odnosno u Općini Ivanec. Pri tome se ivanečku općinu analizira kao svojevrsnu studiju slučaja u širem kontekstu nastanka i razvoja potrošačkoga društva u Jugoslaviji od sredine 1950-ih do početka 1970-ih.

Budući da je u Ivancu, unutar istog poduzeća, osnovana i prva putujuća samoposluga u Jugoslaviji, postavlja se i dodatno istraživačko pitanje - je li mjesto Ivanec u socijalističkoj Jugoslaviji imalo ulogu mikrolokacije na kojoj je državna vlast provodila svojevrsne ekonomske eksperimente iz sfere samoposlužne trgovine? Naime, budući da je koncept samoposluživanja dotad bio vezan ponajprije za zapadne kapitalističke ekonomije, njegovo uvođenje bio je pothvat koji je za sobom nosio značajne političke i ideološke konotacije. Relevantne recentne studije uvođenje samoposluživanja u socijalističku Jugoslaviju vide kao jedan od značajnih segmenata pojave potrošačkog društva (Duda) i amerikanizacije (Vučetić) Jugoslavije, pa se ovdje postavlja pitanje je li jugoslavenska vlast imala utjecaja i na pojavu trgovinskih novotarija u malenome Ivancu ili su te pojave imale neke druge uzroke?

U članku će se najprije predstaviti nastanak i razvoj koncepta samoposluživanja u svijetu i u Europi, da bi se potom naznačili osnovni preduvjeti za pojavu samoposluživanja u Jugoslaviji. Potom će se detaljnije obraditi dva pionirska događaja vezana za Ivanec - otvaranje prve samoposluge i pojava prve putujuće prodavaonice u Jugoslaviji - te će se pokušati utvrditi koliko su ti događaji i pojave

Pogledati npr. GOLDSTEIN 2008; RADELIĆ 2006; MATKOVIĆ 2003; BILANDŽIĆ 1999.

4 To su: KUŠEN 2012; Isti 2009. Šture informacije o ivanečkoj samoposluzi donosile su i neke dnevne novine i portali prigodom nekih obljetnica. Vidi ZEGNAL 2006; NOVAK I ČVELJO 2009. 
utjecali na svakodnevni i društveni život ljudi toga kraja. Na kraju će se predstavljene činjenice interpretirati u kontekstu razvoja jugoslavenskog gospodarstva, svakodnevice jugoslavenskog stanovništva te međunarodnog političkog konteksta.

\section{Nastanak koncepta samoposluživanja i njegova pojava u Europi}

Na samim počecima maloprodaje proizvodi su kupcu bili dostupni isključivo preko osobe trgovca. Proizvodi su se nalazili na polici iza njega, a kupci su morali prodavaču reći što točno traže. Isto tako, većina hrane i robe nije bila dostupna u pakiranju, već je trgovac bio taj koji je, prema želji kupca, pakirao potrebnu količinu željene namirnice. ${ }^{5}$ To je često nudilo mogućnost za društvenu interakciju pa su kupci taj stil kupovanja smatrali društvenim događajem i često bi se zaustavili da porazgovaraju s osobljem ili drugim kupcima. ${ }^{6}$ Ti su postupci, sa stajališta ekonomske učinkovitosti, bili spori i skupi jer je broj kupaca bio ograničen uslugama prodavača, odnosno istodobno se nije moglo poslužiti više kupaca nego što je bilo prodavača u dućanu. Prvi je taj problem riješio poduzetnik iz SAD-a, Clarence Saunders (1881. - 1953.), svojim lancem samoposluga Piggly Wiggly, u kojemu su kupci sami imali mogućnost dohvata robe bez posredovanja prodavača, a što je utjecalo na veću protočnost i brzinu kupnje namirnica. ${ }^{7}$ To je s jedne strane podrazumijevalo npr. da u prodavaonici ne treba više raditi petero ili više radnika, već dvoje ili troje. Jedan bi radio na blagajni, a drugi bi stavljali robu na police. S druge strane, kupci su štedjeli svoje vrijeme jer nisu više direktno ovisili o prodavaču koji im je istodobno vagao i pakirao robu. Tako se smanjivalo i čekanje u redovima, ali i povećavala efikasnost prodaje. Prvi je dućan Saunders otvorio 1916. godine u Memphisu (Tennessee, SAD), a potom je svoj koncept trgovine patentirao i razvijao. Velika financijska uspješnost samoposluga rezultirala je time da je Saunders počeo dijeliti i franšize.

U Europi se samoposluge javljaju nešto kasnije, pred Drugi svjetski rat. Prema najnovijim istraživanjima, prva samoposluga u Europi otvorena je 1938. u njemačkome gradu Osnabrücku, a druga tek 1941. u švedskome Stockholmu. ${ }^{8} \mathrm{U}$ ratnome vihoru malobrojne su europske samoposluge uglavnom nestale, a njihova ponovna pojava nakon završetka Drugoga svjetskog rata predstavljala je jedan od segmenata amerikanizacije Europe. ${ }^{9}$ SAD-ov Plan europske obnove iz 1947. (tzv. Marshallov plan), odnosno program ekonomske pomoći poslijeratnoj Europi sa

\section{HAMLET 2008.}

6 Isto.

7 Piggly Wiggly: About us. http://www.pigglywiggly.com/about-us. (posjet 20. 4. 2016); vidi i DUDA 2003: 272.

8 KLOPPENBORG 2016: 428.

9 Opširnije o amerikanizaciji Europe u 20. stoljeću vidi DE GRAZIA 2005. 
sobom je nosio i ideju stvaranja potrošačkoga društva prema američkome modelu. ${ }^{10}$ Prema najnovijim istraživanjima, razvoj maloprodaje, u čemu je samoposluživanje bilo glavni pokretač, imao je ključnu ulogu u nastanku potrošačkoga društva poslijeratne Europe. ${ }^{11}$ Velika Britanija bila je europska predvodnica u uvođenju samoposluga nakon rata, pa ih je 1947. godine u toj zemlji bilo već oko deset. ${ }^{12}$ Ipak, prva samoposluga nakon Drugog svjetskog rata u Europi je otvorena opet $u$ Švedskoj 1946. godine, prije pojave Marshallova plana, što govori da su Šveđani imali afinitete prema konceptu samoposluživanja neovisno o procesu amerikanizacije Europe nakon Drugoga svjetskog rata. No, ovi izolirani švedski primjeri ne osporavaju činjenicu da je koncept samoposluživanja u Europi ponajviše raširen u procesu amerikanizacije. ${ }^{13}$ Budući da je jedan od glavnih ciljeva Marshallova plana bilo suzbijanje komunističkoga utjecaja u Europi, amerikanizacija Europe bila je ograničena stvaranjem tzv. željezne zavjese pa su i samoposluge ostale privilegija kapitalističkoga svijeta. Onaj socijalistički na svoje prve samoposluge čekao je gotovo čitavo desetljeće.

Iako su se vlasti socijalističkih zemalja protivile amerikanizaciji, i one su pokušavale opskrbiti svoje građane ,svim potrepštinama kojima je bio opijen truli kapitalizam. "14 No, premda su socijalističke države jamčile građanima osnovnu materijalnu egzistenciju, socijalističke ekonomije nisu bile u stanju osigurati dobru opskrbljenost, izbor, niti kvalitetu proizvoda. ${ }^{15}$ Pored toga, u socijalističkim ekonomijama u prvom poratnom desetljeću čekanja u redu na željenu robu, kao i čežnja za proizvodima kojih nije bilo predstavljali su svakodnevicu građana, pa se teško može govoriti o tipu potrošnje kakav je postojao u kapitalističkim ekonomijama, iako je i u njima potražnja često prelazila mogućnosti ponude. ${ }^{16}$ Konzumerizam će u socijalističke zemlje početi prodirati tek nakon što Nikita Hruščov pokrene proces destaljinizacije u SSSR-u, a time i u drugim zemljama Istočnoga bloka od sredine 1950-ih. U tom procesu, prema Berendu, najviše su otišle Jugoslavija i Mađarska, dok se u drugim socijalističkim zemljama, poput Čehoslovačke i Bugarske, barem poboljšala opskrbljenost tržišta. ${ }^{17}$

Jedan od prvih primjera samoposluge u socijalističkoj zemlji jest ona iz Njemačke Demokratske Republike, koja je otvorena 5. lipnja 1956. godine na 147

\footnotetext{
VUČETIĆ 2012b: 278.

JESSEN I LANGER 2016: 5.

2 HAMLET 2008.

13 KLOPPENBORG 2016: 428.

14 DUDA 2005: 41.

15 PERSSON 2010: 195-199.

16 VERDERI 2005: 54-55.

17 BEREND 1996: 164.
} 
kvadratnih metara površine u mjestu Halle an der Saale. ${ }^{18}$ Ta je samoposluga osnovana ugledajući se na iskustva iz Savezne Republike Njemačke i iz skandinavskih zemalja, a glavni cilj osnivača bilo je povećanje efikasnosti rada, odnosno smanjenje broja radne snage i utroška radnoga vremena. ${ }^{19}$

\section{Preduvjeti i začeci ideje samoposluge u Jugoslaviji}

Kraj pedesetih i šezdesete godine prošloga stoljeća u Europi obilježio je, u generalnom trendu, značajan gospodarski rast zbog kojeg se to razdoblje često i naziva zlatnim dobom, kako ga je definirao Eric Hobsbawm, ${ }^{20}$ ili dobom obilja, kako je to interpretirao Tony Judt. ${ }^{21}$ Gledano u cjelini, Europljani su 1960-ih godina dostigli standard kakav je bio nezamisliv prije Drugoga svjetskog rata.

U isto je vrijeme i Jugoslavija, i Hrvatska kao njen dio, također doživjela značajan gospodarski rast. ${ }^{22}$ Taj rast bio je obilježen i pojavom potrošačkog društva, čiji je početak teško precizno datirati. ${ }^{23}$ Benson i Stearns definiraju potrošačka društva kao ona „u kojima su izbor i kredit lako dostupni, u kojima su društvene vrijednosti određene kupovnom moći i materijalnim vlasništvom, i u kojima postoji želja za, iznad svega, onim što je novo, suvremeno, uzbudljivo i moderno“. ${ }^{24}$ Upravo krajem 1950-ih u Jugoslaviji su se želje i mogućnosti građana poklopile s dovoljnom proizvodnjom i ponudom proizvoda i usluga. ${ }^{25}$

Drugi svjetski rat donio je veliki pad životnoga standarda na prostoru Jugoslavije. Na kraju i neposredno nakon rata stanovništvo je bilo na rubu gladi i u velikoj je mjeri ovisilo o pomoći UNRRA-e (United Nations Relief and Rehabilitation Administraton). ${ }^{26}$ Jugoslavija je, ušavši u Staljinov lager završetkom rata, prihvatila i sustav petoljetki, tako da se plansko gospodarstvo predstavljalo kao izlaz

\footnotetext{
18 Das Dokumentationszentrum Alltagskultur der DDR 2006: 29.

19 Isto.

20 HOBSBAWM 2009.

21 JUDT 2007: 324-353.

22 Opširnije o hrvatskom gospodarstvu u tom razdoblju vidi STIPETIĆ 2012: 304-328; VOJNIĆ 2008. Treba naglasiti da je Jugoslavija u dvadesetogodišnjem razdoblju od 1950. do 1970. u odnosu na druge europske zemlje, prema kriteriju BDP-a per capita, i dalje bila gotovo na začelju. Vidi VACIĆ 1989: 36. Prema Zdenku Radeliću, druge su se europske zemlje, koje su bile približno jednako razvijene kao i Jugoslavija, u to vrijeme razvijale još i brže i uspješnije, pa je Jugoslavija unatoč svojem razvoju i dalje bila na dnu europske ljestvice prema razvijenosti. RADELIĆ 2006: 337-338.

23 DUDA 2005: 20.

24 STEARNS 1997: 105; BENSON 1994: 4; prema DUDA 2005: 22.

25 DUDA: 23.

26 Opširnije o pomoći koju je Jugoslavija primila od UNRRA-e vidi AJLEC 2013.
} 
iz krize. ${ }^{27}$ Prema Dudi, jugoslavensko se gospodarstvo prvih poratnih desetljeća razvijalo u trima etapama: 1945 . - 1952., 1952. - 1965. i 1965. - 1975. ${ }^{28}$ Prvu etapu obilježavao je prvi petogodišnji plan, kreiran po uzoru na SSSR, koji je predviđao izrazito centraliziranu ekonomiju s jakim središnjim administrativnim državno-partijskim nadzorom. ${ }^{29}$

Početkom 1950-ih, na početku druge etape, unatoč povećanju proizvodnje, standard nije uspio doseći predratnu razinu. Unatoč proklamiranju samoupravljanja od početka 1950-ih, državni je utjecaj na ekonomiju i dalje ostao velik, a državni privredni planovi nisu potpuno napušteni, ${ }^{30} \mathrm{o}$ čemu svjedoči i niz jednogodišnjih planova (1952. - 1957.) te dvije petoljetke (1957. - 1961. i 1961. - 1965.) u drugoj etapi ekonomskog razvoja. Ipak, u toj etapi dogodio se i najveći jugoslavenski gospodarski rast, pogotovo u razdoblju od 1953. do 1961., kad je Jugoslavija nakon Japana imala najvišu stopu industrijskog razvoja u svijetu. ${ }^{31} \mathrm{U}$ razdoblju od 1953. do 1956. godine prosječni je godišnji rast proizvodnje u Jugoslaviji iznosio 9,5 $\%$, a privatne potrošnje $10 \%$, što je jugoslavenski privredni rast svrstavalo među najveće na svijetu. ${ }^{32} \mathrm{U}$ razdoblju od 1958. do 1964. godine nacionalni se dohodak po stanovniku povećao po stopi od 7,6 \%, a došlo je do uvećanja izvoza za $121 \%$ i uvoza za $98 \%{ }^{33}$ Taj rast posljedica je promijenjene jugoslavenske ekonomske politike, ali i znatne ekonomske pomoći SAD-a ${ }^{34}$, u čijim je vladajućim krugovima od 1951., zbog hladnoratovskog konteksta, prevladalo mišljenje da o ekonomskoj stabilnosti Jugoslavije ovisi i njena obrambena sposobnost. ${ }^{35}$ Jugoslavija je u petogodišnjem razdoblju do 1955. dobila oko 500 milijuna američkih dolara ekonomske pomoći i oko 800 milijuna dolara kratkoročnih i srednjoročnih kredita. ${ }^{36}$

U drugoj etapi, ohrabrena značajnim gospodarskim rastom, jugoslavenska vlast bila je svjesna da rastom industrije stanovništvu mora omogućiti bolje životne uvjete. To je već od 1955. jasno naglašavao i Josip Broz Tito. Tako je 26. rujna 1955. u svom govoru prilikom otvaranja hidrocentrale kod Zvornika rekao da se socijalizam ostvaruje industrijalizacijom, socijalnom pravdom te ostvarenjem

\footnotetext{
Opširnije o karakteru i problemima jugoslavenske ekonomije u prvom petogodišnjem planu vidi DOBRIVOJEVIĆ 2013: 19-33.

28 DUDA 2005: 43.

29 GOLDSTEIN 2008: 476.

30 DOBRIVOJEVIĆ 2013: 35.

31 BILANDŽIĆ 1999: 387.

32 VUČETIĆ 2012b: 280.

33 PEROVIĆ 1991: 31.

34 DOBRIVOJEVIĆ 2013: 39.

35 BEKIĆ: 247; DOBRIVOJEVIĆ 2013: 33.

36 DOBRIVOJEVIĆ 2013: 39.
} 
višeg životnog standarda ${ }^{37}$ i naglasio da će se graditi poduzeća „,koja će se odraziti što prije na poboljšanje životnog standarda naših radnih ljudi.“38 Slično je ponovio i u razgovoru s delegacijama gradova 1. veljače 1956., rekavši:

„Mi smo ove godine morali preorijentisati svoju privredu i išli smo na smanjenje svojih napora u izgradnji teške industrije, da bismo koraknuli dalje u pravcu izgradnje onoga što će u izvjesnom smislu brzo poboljšati standard naših radnih ljudi." ${ }^{\text {(39 }}$

Ta ideja dobila je i svoju teorijsku artikulaciju na Sedmome kongresu Saveza komunista Jugoslavije (SKJ), održanom 1958. godine u Ljubljani, kada je usvojen Program SKJ koji se, između ostalog, založio i za podizanje životnog standarda i potrošnje stanovništva te naglasio potrebu „boljeg usluživanja potrošača robom“. 40 Duda tvrdi da je u Jugoslaviji krajem pedesetih i šezdesetih godina potrošačka kultura postala i važnim dijelom politike SKJ jer se smatralo da će radnik koji više radi i zarađuje više i kupovati, odnosno trošiti. Smatralo se da će povećana potrošnja čovjeka učiniti sretnijim zbog povećanja standarda, odnosno poboljšanja uvjeta života. ${ }^{41}$

Najavljeno poboljšanje životnoga standarda doista se i dogodilo, prvenstveno kao popratna pojava rasta gospodarstva koje se sve više orijentiralo na laku industriju i proizvodnju robe široke potrošnje. ${ }^{42}$ Porastom standarda i pojedinac si je mogao priuštiti više stvari te uživati u konzumerizmu, dakako, na ograničeni socijalistički način. Stvaranje potrošačkoga društva u Jugoslaviji jasno je vidljivo upravo u razvoju samoposlužnoga oblika trgovine. Jugoslavija će u drugoj polovini 1950-ih dobiti i svoje prve samoposluge kao posljedicu gospodarskoga rasta te utjecaja sve veće amerikanizacije, koja počinje dobivati na zamahu krajem 1950-ih godina. ${ }^{43}$

Razvoj samoposluživanja puni će zamah dosegnuti u trećoj etapi razvoja jugoslavenskog gospodarstva, započetoj privrednom reformom 1965. godine, kojom se nastojalo smanjiti ulogu države u gospodarstvu. U tom razdoblju doći će do daljnjeg jačanja osobne potrošnje i prihoda, modernizacije i učinkovitosti poslovanja, kao i veće slobode tržišta. ${ }^{44}$

\footnotetext{
BROZ TITO 1959: 274.

38 Isto: 275; vidi i DOBRIVOJEVIĆ 2013: 41.

39 BROZ TITO 1976: 117.

$40 \quad$ VII kongres Saveza komunista Jugoslavije 1958: 375, 377.

41 DUDA 2005: 47.

42 VUČETIĆ 2012b: 279-280.

43 Detaljnije informacije o amerikanizaciji, njezinu značenju i utjecaju na Jugoslaviju vidi u VUČETIĆ 2012a.

44 DUDA 2005: 44.
} 


\section{Otvaranje prve jugoslavenske samoposluge}

U poslijeratnoj trgovini zbog prisutnog distributivnog trgovanja sve do 1950 . godine nije bilo moguće provoditi nikakvu specijalizaciju, niti neke radikalnije promjene na unapređivanju te djelatnosti. Uvjeti su se nešto izmijenili kroz idućih pet godina jer je bilo sve više industrijskih roba, a počelo se djelovati i na proširenju prodajnoga i skladišnoga prostora. U tim uvjetima bila je ponuđena inicijativa razvoja kulturnoga usluživanja, približavanja trgovaca potrošačima s ciljem da se što više uvažavaju njihove želje i zahtjevi. Usporedno su trgovinske komore vrlo intenzivno radile na povezivanju trgovine i proizvodnje, održavala su se predavanja i seminari, a upravo će jedno od tih predavanja inspirirati direktora jednog trgovačkog poduzeća iz Ivanca na ideju o otvaranju prve samoposlužne prodavaonice u Jugoslaviji. Prva samoposluga u Jugoslaviji, ali i u čitavoj jugoistočnoj Europi, otvorena je u prosincu 1956. u Ivancu, malom mjestu u Hrvatskom zagorju. ${ }^{45}$

Nakon završetka Drugoga svjetskog rata Ivanec se, kao i čitava Jugoslavija, nalazio u teškoj ekonomskoj i gospodarskoj situaciji. Jedan od razloga tomu ležao je i u činjenici da su proizvodni kapaciteti bili slabi ${ }^{46}$ Stanovništvo se većinom bavilo poljoprivrednom djelatnošću, a uz to je i bilo zaposleno u poljoprivrednome sektoru. ${ }^{47} \mathrm{U}$ okolnostima $\mathrm{u}$ kojima poljoprivredna proizvodnja dominira $\mathrm{u}$ proizvodnji teško je zamisliti da bi se mogla javiti i realizirati ideja o otvaranju prve samoposluge. Neposredno nakon Drugoga svjetskog rata u Ivancu nije bilo dovoljno ni prodajnog prostora ni robe, ${ }^{48}$ ali je $\mathrm{s}$ vremenom došlo do porasta industrijske aktivnosti koju je pratila i trgovina. ${ }^{49}$

Izvršni odbor Narodnog odbora kotara Ivanec,${ }^{50}$ pod predsjedništvom Alojza Habrke, 24. travnja 1947. godine donio je odluku o osnivanju Kotarskog nabavnog poduzeća „Bistrica“ ${ }^{51}$ Za direktora je bio imenovan Ćiril Bregović, a poduzeće je počelo raditi 1. srpnja 1947. godine s trima prodavaonicama i imalo je 37 za-

\footnotetext{
45 Zanimljiva je činjenica da razvijenije zemlje europskoga Zapada poput Italije 1956. godine još nisu imale samoposluge. SCARPELLINI 2016: 56; Ista 2004.

46 Za detaljnije informacije vidi LAMPE 1996: 115-119, 148-150, 168-170, 184-185.

47 VRČEK 1979: 10-11.

48 Veliki datum jugoslavenske trgovine, VA-MA: Informativni list radne zajednice Varaždinskog magazina Varaždin (dalje: VA-MA), 28. prosinca 1972.: 6-7.

49 Opširnije o razvoju ivanečke privrede u prvim dvama poslijeratnim desetljećima vidi Godine socijalističke izgradnje Općine Ivanec 1945.-1965. 1965.

50 Uvođenjem komunalnog sistema 1955. Ivanec više nije bio kotar, nego je Općina Ivanec ušla u sastav kotara Varaždin. Vidi Narodni odbor kotara Varaždin, Arhinet - Hrvatski državni arhiv. http://arhinet.arhiv.hr/details.aspx?ItemId=3_13268 (posjet 21. 4. 2016).

51 Srebrni jubilej „Ivanečkog magazina“, VA-MA, 15. rujna 1972.: 10.
} 
poslenih. ${ }^{52}$ Poduzeće je u idućih nekoliko godina raslo, ali i više puta mijenjalo naziv. Godine 1949. mijenja naziv u „Naprijed“, kotarsko-nabavno poduzeće Ivanec i tada ima već 22 prodavaonice i 72 zaposlenih. ${ }^{53}$ Godine 1952. službeno je ime poduzeća Trgovačko poduzeće „Naprijed“, a 1954. godine mijenja ime u „Ivanečki magazin“, s time da su ga zaposlenici i stanovništvo otad najčešće nazivali skraćenicom - IMA. ${ }^{54}$ Dana 1. travnja 1971. godine IMA je pristupila većem poduzeću - „Varaždinskom magazinu“ (VA-MA), ${ }^{55} \mathrm{u}$ sklopu kojeg će od 1972. godine djelovati kao Osnovna organizacija udruženoga rada (OOUR). ${ }^{56}$

Samoupravljanje je u poduzeće uvedeno 10. rujna 1950., kad je izabran prvi radnički savjet. ${ }^{57}$ Od te godine na rukovodnoj funkciji u „Ivanečkom magazinu“ bio je direktor poduzeća Andrija Sever (1921. - 1991.), jedan od tada poduzetnijih ljudi u ivanečkoj općini. On nije bio zadovoljan tadašnjim rezultatima poslovanja, a pogotovo ga je zabrinjavao problem malih prodajnih kapaciteta. U tim su trgovinama trgovci radili tradicionalnim načinom koji je bio spor, zbog čega su se kupci gomilali i čekali u dugačkim redovima. Pored problema velikih i čestih gužvi, često se događalo i da se roba brzo rasproda i nestane s polica. ${ }^{58}$

Sever je 1954. godine s nekolicinom suradnika u Radničkome domu u Zagrebu slušao predavanja poduzetnika iz SAD-a, u kojima je, uz ostalo, objašnjeno i racionalno proširivanje prodajnih kapaciteta. Tada je prvi put čuo da se u SAD-u sve više širi prodaja robe široke potrošnje na principu samoposluživanja, čime se iskorištavao poslovni prostor za prodaju većih količina robe.$^{59}$ Sever je slušao o tome kako u SAD-u kupci šeću sami među robom, sami je uzimaju i da se sve odvija velikom brzinom. ${ }^{60} \mathrm{U}$ svom prisjećanju iz 1976. godine, prigodom dvadesete obljetnice otvaranja samoposluge, Sever je naglasio:

\footnotetext{
52 Isto.

53 Isto.

54 Suvremeno trgovanje u Ivancu, Ivanečki kalendar 1974: 26.

55 Isto.

56 PUHALOVIĆ 1972:1.

57 Suvremeno trgovanje u Ivancu, Ivanečki kalendar 1974: 26.

58 Veliki datum jugoslavenske trgovine, VA-MA, 28. prosinca 1972.: 6-7.

59 KOŽAR 1986a.
}

60 Veliki datum jugoslavenske trgovine, VA-MA, 28. prosinca 1972.: 6-7. Racionirana opskrba stanovništva vezana je prvenstveno za prvo desetljeće nakon Drugoga svjetskoga rata, kada se zbog sveopće devastiranosti gospodarstva u Jugoslaviji primjenjivao državni model opskrbe koji se sastojao u utvrđivanju minimalnih dnevnih potreba pojedinca, odnosno minimalnih količina ponajprije prehrambenih, ali i svih drugih potrošačkih proizvoda, na osnovi čega se nastojala prilagoditi proizvodnja na razini čitave države. Takav način opskrbe poništavao je tržišne principe trgovine, a stanovništvo je, umjesto novcem, do proizvoda dolazilo potrošačkim karticama i novčanim bonovima. Takav način opskrbe ukinut je uglavnom do 1953. godine. O tome više MATICKA 1999. 
„Nama to tada uopće nije išlo u glavu: kako da pustimo kupca među robu, da 'švrlja' po dućanu, jer se zna da ima takovih mušterija koje i uz svu pažnju prodavačkog osoblja nešto 'dignu'. A što bi tek bilo kad bi ih pustili da sami izabiru?! Tada je bilo i nešto robe na racioniranom snabdijevanju uz točkice, karte i kupone, pa je zato bilo još više neshvatljivo kako bi se u našoj praksi moglo uvesti samoposluživanje. Vjerojatno će još proći mnogo vremena dok do toga dođe, a možda toga kod nas nikada neće ni biti, znali smo međusobno komentirati." ${ }^{\text {"61 }}$

Međutim, za nekoliko se godina situacija izmijenila: više nije bilo garantiranog snabdijevanja, nestale su točkice, karte i kuponi, povećan je asortiman roba široke potrošnje domaće i inozemne proizvodnje. Sever je, prepoznajući nove uvjete, i s ciljem da se proda što više robe, početkom 1956. godine predložio stručnim suradnicima i radničkom savjetu poduzeća da jedan lokal pretvori u trgovinu mješovite robe i kućnih potrepština na principu samoposluživanja. O tome je sastavio i elaborat kojim je dokazivao da će samoposluživanjem doći do većeg protoka robe na istom prostoru i veće produktivnosti rada nego klasičnom prodajom. Jedan dio zaposlenih pakirat će robu i stavljati je nadohvat kupcu, a drugi će od kupca odabranu robu naplaćivati. Dokazivao je da će tako i prodavačko osoblje imati manje fizičkog napora te da će se u konačnici produktivnost znatno podignuti u odnosu na klasični način prodaje. ${ }^{62}$

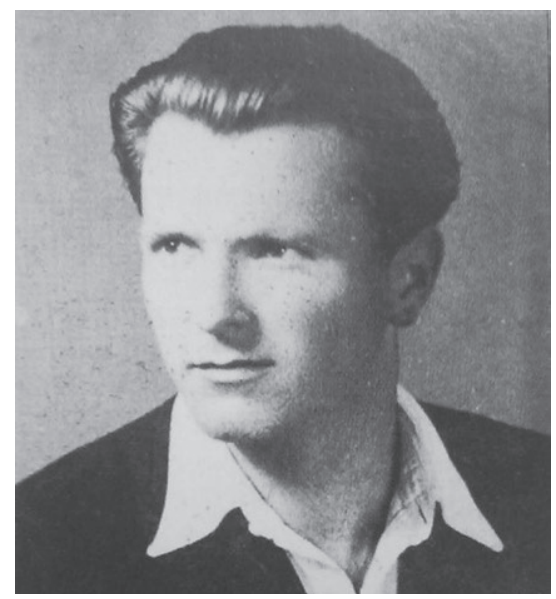

Slika 1: Andrija Sever (1921. - 1991.) $)^{63}$

Za svoju ideju nije odmah dobio podršku ni među stručnim suradnicima ni kod radničkoga savjeta. Prema Severu, glavni razlog protivljenja bio je stav da će mušterije krasti, ako ih se pusti da same slobodno „švrljaju“ po dućanu jer ni dotad krađe nisu bile rijetkost. Ipak, Sever je za svoju ideju uspio pridobiti

\footnotetext{
61 KOŽAR 1976: 5.

62 Isti 1986a.

63 KUŠEN 2012: 53.
} 
naklonost nekolicine kolega, među kojima se posebno istaknuo Stjepan Putarek (1922. - 1999.), tadašnji komercijalni rukovodilac, koji se, prema Severovim riječima, za tu ideju i njenu provedbu založio više i od njega samoga. ${ }^{64}$ Zajedno s Putarekom dao je općinskim čelnicima prijedlog za otvaranje prve samoposluge u općini, u kojoj je Sever bio zadužen za financijsku konstrukciju, a Putarek se bavio tehničkim poslovima. ${ }^{65}$ Budući da u to vrijeme nije postojalo iskustvo sa samoposlugama, svi su bili skeptični u vezi s otvaranjem samoposluge i njezinom isplativošću. No, nakon strpljivog uvjeravanja i objašnjavanja pridobili su većinu ljudi u poduzeću te su potom tražili i političku podršku od Narodnog odbora Općine Ivanec. Narodni odbor dao je podršku i za samoposlugu izdvojio novčana sredstva u iznosu od 580.000 dinara. ${ }^{66}$ Iz Zapisnika s X. izdvojene sjednice Općinskog vijeća Narodnog odbora Općine Ivanec, održane 29. svibnja 1956. godine, može se iščitati da je Narodni odbor bio zadovoljan postignutim rezultatima u veletrgovačkom poduzeću „Ivanečki magazin“. Od poduzeća se očekivalo izvjesno povećanje robnog prometa u odnosu na prošlu godinu, a tom je povećanju značajno trebala pridonijeti i samoposluga, proširenjem trgovačke mreže za špeceraj te proširenjem skladišnog prostora, za što su bila predviđena sredstva iz samog poduzeća, ali i Narodnog odbora ${ }^{67}$ Konačno je 16. srpnja 1956. radni kolektiv donio odluku da će se samoposluga ipak otvoriti. ${ }^{68}$

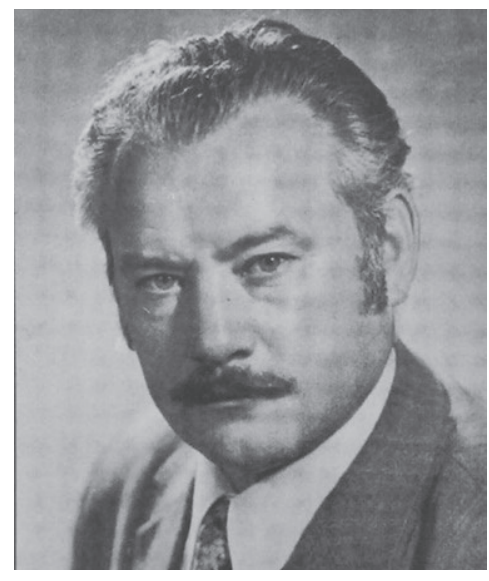

Slika 2: Stjepan Putarek (1922. - 1999. $)^{69}$

64 KOŽAR 1986a: 5.

65 Veliki datum jugoslavenske trgovine, VA-MA, 28. prosinca 1972.: 6-7.

66 Suvremeno trgovanje u Ivancu, Ivanečki kalendar 1974: 23.

67 Državni arhiv u Varaždinu (dalje DAVŽ), 35. Narodni odbor kotara Varaždin, 1. 2. 2. Zapisnici sjednica NOO Ivanec 1955. - 1957., Zapisnik sa X. izdvojene sjednice Općinskog vijeća Narodnog odbora općine Ivanec, od 29. svibnja 1956.: 4.

68 Suvremeno trgovanje u Ivancu, Ivanečki kalendar 1974: 23.

69 KUŠEN 2012: 53. 
Prva samoposluga, zasebna prodajna jedinica unutar IMA-e, otvorena je 17. prosinca 1956. godine. Bila je smještena u jednoj od sporednih ulica u Ivancu, nasuprot ivanečke crkve Sv. Marije Magdalene, jer su i sami inicijatori ideje o samoposluzi bili svjesni da bi neuspjeh u poslovanju imao negativan publicitet za njihovu reputaciju. ${ }^{70}$ Godine 1960 . samoposluga je premještena u Ulicu Josipa Kraša, jednu od prometnijih ivanečkih ulica. ${ }^{71}$ Otvorena je u dotadašnjem skladištu poduzeća, a kao dodatni razlog zbog čega je odabrana baš ta lokacija bila je i činjenica da je to skladište imalo dvoja vrata, tako da je samoposluga imala odvojen ulaz od izlaza. Potrošači su se kretali u jednom smjeru, uzimali su robu, a na kraju plaćali na blagajni. Samoposluga se prostirala na površini od 75 četvornih metara i bila je opremljena drvenim policama. ${ }^{72}$ Tada se u Jugoslaviji nije proizvodila oprema za ovu vrstu prodavaonica, pa su Andrija Sever i Stjepan Putarek sami pravili nacrte i davali funkcionalna i tehnička rješenja za opremu. Kako je u tom vremenu bilo uobičajeno da se inventar radi od drveta, prodavaonicu je opremio stolarski pogon Opće poljoprivredne zadruge u Ivancu. ${ }^{73}$ Tada još nije bilo ni metalnih košara, pa su prve košare bile načinjene od vrbina granja. ${ }^{74}$ Stigle su i registar-blagajne, a stvoreni su i potpuno novi odnosi potrošača i prodavača koji su u kontakt dolazili tek kad je kupac plaćao robu. ${ }^{75}$

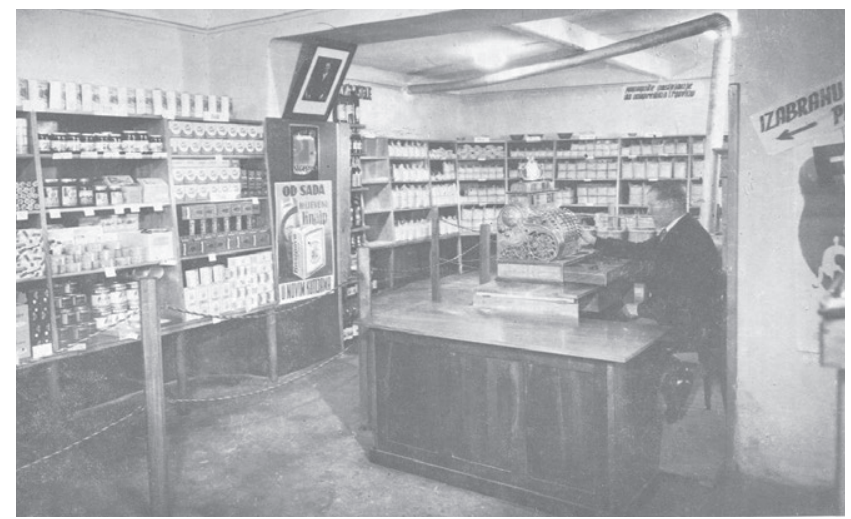

Slika 3: Unutrašnjost samoposluge u Ivancu $1956 .^{76}$

70 Državna geodetska uprava (DGU), Katastar Ivanec, Gruntovnica Ivanec, Zemljišno-knjižni uložak 17. U početku je navedeno zemljište bilo u posjedu obitelji Babić. Godine 1937. ovrhom na javnoj dražbi parcela pripada Franji Lukačeku. Već 1959. godine, odnosno tri godine nakon osnivanja samoposluge zemljište se otpisuje u Općenarodnu imovinu, a 1960. nacionalizirano je. Godine 1971. kao vlasnica upisana je Đurđa Putarek, supruga Stjepana Putareka.

71 Ulice i trgovi Ivanca, Ivanečki kalendar 1974.: 27.

72 Veliki datum jugoslavenske trgovine, $V A-M A, 28$. prosinca 1972.: 6-7.

73 Suvremeno trgovanje u Ivancu, Ivanečki kalendar 1974: 23.

74 Pionirski pothvat iz Ivanca, Varaždinske vijesti, 25. rujna 1986.

75 Veliki datum jugoslavenske trgovine, VA-MA, 28. prosinca 1972.: 6.

76 Suvremeno trgovanje u Ivancu, Ivanečki kalendar 1974: 24. 
Pored izlaganja proizvoda, trebalo je propagirati i pojašnjavati novi način trgovanja, što su rješavali parolama koje su se nalazile na odgovarajućim mjestima po prodavaonici, kao npr.: „Robu izvolite izabrati sami““ ili „Obavezno uzmite košaricu“. Prostorom je dominirao natpis: „Potrošači cijenimo vaše poštenje“, a kod blagajne je pisalo: „Izabranu robu izvolite ovdje platiti“. Da se ne bi mnogo „pipalo“ po izloženom kruhu, već da onaj koji se dotakne bude i uzet, stajala je parola: „Ne biraj“ ${ }^{77}$ Putarekov zadatak bio je i obilazak proizvođača radi osiguravanja što ljepše pakirane robe, po mogućnosti što atraktivnije, zbog čega su od proizvođača zahtijevali prikladnu ambalažu. Tako je poduzeće „Bednja“ iz Ludbrega počelo pakirati brašno u vrećicama od jednog kilograma. Ono što nije mogla pakirati proizvodnja, pakirali su u vlastitoj skromnoj pakirnici. ${ }^{78}$ Poduzetni su trgovci u svoju novu prodavaonicu kupce privlačili promotivnim lecima u kojima su naglašavali kako samoposluga štedi vrijeme kupcu, nudi mu veći komfor bez čekanja u redovima, a usto su pozivali građane da prilikom posjeta u knjigu želja ostave svoje mišljenje, prijedloge za rad prodavaonice i želje za proširenje asortimana (Slika 4).

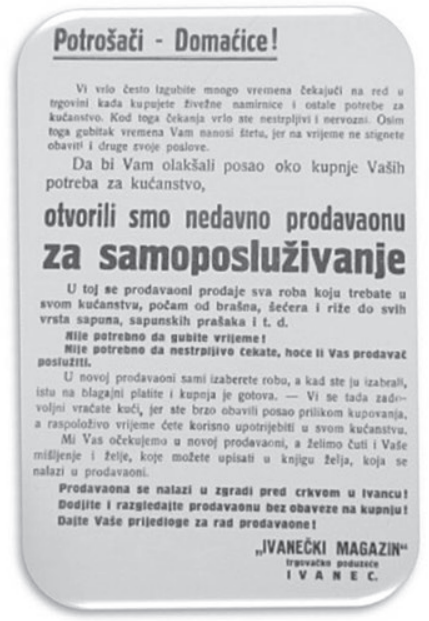

Slika 4: Poziv potrošačima da dođu u samoposlugu ${ }^{79}$

U prvim mjesecima prodaja u samoposluzi bila je manja nego u klasičnoj prodavaonici i nije ostvaren očekivani promet, zbog čega je prijetila opasnost da se samoposlugu opet preuredi u klasičnu prodavaonicu. ${ }^{80}$ Sever i Putarek su, želeći

\footnotetext{
77 KOŽAR 1976: 8.

78 Isti 1986b.

79 Isti 1976: 4.

80 Isti 1986a.
} 
saznati uzroke slabih rezultata, u maniri ozbiljnih ekonomista ispitivali svoje malo ivanečko tržište, anketirajući potrošače upitom zašto su se suzdržavali od kupnje u toj prodavaonici. Njihov zaključak bio je taj da su potrošači bili nepovjerljivi i nenaviknuti na takav novi način kupovanja, a među brojnim razlozima koje su potrošači navodili istaknule su se izjave poput: „Ne idem u taj dućan da ne bi prodavači mislili da sam zato došao da nešto 'dignem' "“81 Neki građani bili su uplašeni misleći da je taj dućan bio svojevrsna zamka - da ga je postavila vlast (policija) kako bi vidjela tko sve hoće krasti. Naime, u to doba „proslavio“ se jedan policijski pas koji je uhvatio nekoliko lopova, pa je po Ivancu proširena glasina da je taj pas skriven u samoposluzi i da čeka kako bi napao potencijalne lopove. ${ }^{82}$ Dodatan problem bio je još uvijek velik broj nepismenog stanovništva koji nije niti razumio napise u samoposluzi pa se teško snalazio unutar nje. ${ }^{83}$

Sever i Putarek su ubrzo reagirali: napravili su neke kadrovske promjene i usavršavali kadar te se počeli truditi na razne načine privući kupce. Prvog poslovođu Adama Brusara i njegova zamjenika Dragutina Hudoletnjaka nakon šest mjeseci zamijenili su poslovođa Ivan Videc i zamjenik Dragutin Županić. ${ }^{84}$ Odlučili su da radno vrijeme ne bude dvokratno, nego non-stop, a između ostalog, molili su nastavnike da dovode školsku djecu u samoposlugu da ih pouče kako se u njoj kupuje. ${ }^{85}$ Širili su asortiman sve raznolikijim tipom artikala koji više nije bio ograničen na osnovne prehrambene proizvode. ${ }^{86}$ Rezultati su bili vidljivi jer je prodavaonica nakon pola godine naglo povećavala promet, dostigla i premašila očekivane rezultate. U 1957. godini ostvaren je promet od 11,776.000 dinara, a kad se 1960., zbog sve većeg broja potrošača, samoposluga preselila u centar Ivanca u veći prostor i kad je kupcima omogućeno da kupuju i dva sata nedjeljom, samoposluga je dosegla promet od $62,936.000$ dinara. ${ }^{87}$

Ipak, ni to možda ne bi bilo dovoljno bez šire političke podrške koju su na kraju ipak dobili. Mirko Ivić-Šiljo, narodni zastupnik Sabora NR Hrvatske, iz kotara Varaždin, u knjizi dojmova je 26. prosinca 1956. godine napisao da takvu vrstu usluživanja smatra vrlo interesantnim potezom ivanečke trgovine jer „treba mijenjati mišljenje o svijesti naših ljudi““. ${ }^{88}$ Još važnija podrška stigla je 12. travnja 1957. godine, kada je samoposluživanje posjetio Risto Bajalski, generalni sekretar

\footnotetext{
81 Isto.

82 Ivanečko samoposluživanje izraz revolucionarnog entuzijazma, VA-MA, 28. prosinca 1972.: 6.

83 Pionirski pothvat iz Ivanca, Varaždinske vijesti, 25. rujna 1986.

84 KOŽAR 1986d.

85 Isti $1986 \mathrm{~b}$.

86 Isto.

87 KOŽAR 1986d.

88 Isto.
} 
Saveza trgovinskih komora iz Beograda, koji je pozdravio kolektiv i direktora te u knjizi dojmova napisao da ,smatra da primjer ove prodavaonice treba biti ogledan za sva naša velika i mala mjesta“ te da treba „poduzeti mjere da se ovaj sistem širi stvarajući mu za to potrebne materijalne uslove." ${ }^{\text {"99 }}$ Prema sjećanjima fotografa Petra Jagetića, Bajalski je prilikom posjeta bio toliko oduševljen radom samoposluge da je obećao jednu talijansku blagajnu kako bi unaprijedio rad samoposluge, koja je ubrzo i stigla u Ivanec. Njegova pozitivna reakcija može se interpretirati i kao podrška djelovanju i razvoju samoposluga s visoke savezne razine. Bajalski je, kao jedan od najviše pozicioniranih dužnosnika iz ekonomskog sektora, uzimanjem ivanečkog primjera kao oglednog naglasio potrebu daljnjeg razvitka samoposluga. Ni najviši jugoslavenski državni vrh nije se protivio pojavi koncepta samoposluživanja. Promocija američke samoposluge na Zagrebačkom velesajmu u rujnu 1957. godine ${ }^{90}$ utjecala je na državni vrh, koji je odlučio poduprijeti taj koncept i u Jugoslaviji pa je Savezno izvršno vijeće (SIV) donijelo plan da u kratkom roku otvori lanac od 60 sličnih samoposluga širom zemlje, ${ }^{91}$ što se i ostvarilo, uglavnom adaptiranjem već postojećih prodavaonica. ${ }^{92}$

Politička je podrška jako utjecala na razvoj samoposluga, što potvrđuje činjenica o njihovu snažnom širenju. Godinu dana nakon ivanečke, 29. prosinca 1957. godine, otvorena je samoposluga u Zagrebu (na adresi Ilica 29) u sklopu trgovačkoga poduzeća „Konzum“, ${ }^{93}$ a kao treća samoposluga u Jugoslaviji u travnju 1958. godine i u Beogradu, koja je ujedno postala i najveća. ${ }^{94}$ Već je početkom 1960. godine u Hrvatskoj radilo trinaest samoposluga, od čega devet na periferiji Zagreba, a planirano je da do kraja 1960. godine u Zagrebu bude 21 samoposluga. ${ }^{95}$ Koliko je bio snažan zamah otvaranja samoposluga u idućih desetljeće i pol govore podaci iz 1975. godine, kad je u SFRJ postojalo ukupno 3.475 samoposluga, od čega je Hrvatska imala 889 samoposluga, Srbija 713, Makedonija 522, Slovenija 499, Vojvodina 388, Bosna i Hercegovina 303, Crna Gora 98, a Kosovo $63 .{ }^{96}$

Već 1958. godine uočila se potreba za širenjem skladišnog i prodajnog prostora. Tada je odlučeno da će se samoposluga pravno potpuno spojiti s „Ivanečkim

$89 \quad$ Veliki datum jugoslavenske trgovine, VA-MA, 28. prosinca 1972.: 6 .

90 Opširnije vidi JAKOVINA 2003: 469-479.

91 VUČETIĆ 2012b: 292. Kao još jedan od argumenata toj tvrdnji, Radina Vučetić navodi podatak da je predsjednik Jugoslavije Josip Broz Tito 1969. tijekom svojeg posjeta Sloveniji zajedno sa slovenskim dužnosnicima Sergejem Krajgerom i Francom Popitom obišao i ljubljanski „Supermarket“, tada najveću samoposlugu u Sloveniji. Isto: 293.

92 SAGRAK 1961: 9-10.

93 KOŽAR 1986c.

94 VUČETIĆ 2012b: 290-291.

95 Isto.

96 KOŽAR 1976: 15. 
magazinom“, a unutar kojega je ona dotada bila zasebna jedinica ${ }^{97} \mathrm{Na}$ toj istoj, odvojenoj sjednici Općinskoga vijeća Narodnoga odbora Općine Ivanec od 23. prosinca 1958. godine, prvi se put ističe i važnost ponude asortimana robe široke potrošnje. ${ }^{98}$

Reakcije ljudi na otvaranje samoposluge u Ivancu bile su različite. Može ih se promatrati na dvjema razinama. Prva je ona što su sami Ivančani i drugi posjetitelji govorili o samoposluzi, a s druge strane, ono što su o samoposluzi pisale novine, koje su na indirektan način formirale stavove stanovnika. U napisima objavljenim u glasilu „Varaždinskoga magazina“ objavljeni su neki od zapisa iz knjige dojmova ${ }^{99}$ Sam direktor, Andrija Sever, smatrao je da će otvaranje ove prodavaonice pridonijeti boljem, jeftinijem i bržem posluživanju potrošača te da će uloženi napori biti opravdani ako samoposluga postane „mjesto za odgajanje naših ljudi i stvaranja povjerenja između potrošača i trgovca“. ${ }^{100}$

Direktorova nadanja u određenoj su se mjeri i ostvarila pa su trgovinu dolazile gledati i skupine iz raznih dijelova Hrvatske, ali i Jugoslavije. Brojni su bili posjetitelji koji su u knjigu dojmova ostavljali svoje komentare na rad samoposluge i na ono što su vidjeli prilikom posjeta Ivancu. Predstavnici poduzeća „Pobjeda“ iz Čakovca 7. svibnja 1957. godine u knjigu dojmova zapisali su: „Posjetili smo prodavaonicu 'posluži se sam' pa smo primijetili da je to jedan suvremeni način posluživanja potrošača, koji ćemo nastojali uvesti i u našem mjestu. “" ${ }^{101}$ Dr. Živorad Baralić s Ekonomskog fakulteta u Beogradu 14. travnja 1973. godine zapisao je: „Čini mi posebno zadovoljstvo što mi se ukazala prilika da posjetim pionire i nosioce progresivnog u razvoju samouslužnog sistema u Jugoslaviji. Želim im sve najbolje. "“102 Dakle, ivanečka samoposluga privlačila je ljude iz struke (ekonomiste i trgovce) koji su nerijetko dolazili vidjeti novi koncept trgovine.

Obični su ljudi reagirali na različite načine, od onih koji su odlučili da u samoposlugu neće ići zato što se nalaze u napasti da bi mogli nešto ukrasti, s obzirom na činjenicu da na robu nitko ne pazi, do onih koji su se smatrali počašćenima jer mogu kupovati sami i pritom uživati puno povjerenje onih koji rade u samoposluzi. ${ }^{103} \mathrm{U}$ tom je smislu vrlo živopisnu opservaciju ostavila posjetiteljica iz Sarajeva, Fatima Hodžić, koja je 27. studenog 1957. zapisala: „Šućur Alahu, da

\footnotetext{
97 DAVŽ, 35, Narodni odbor kotara Varaždin, 1. 2. 2. 4. Zapisnici sjednica. NOO Ivanec 1958, Zapisnik XI. odvojene sjednice Općinskog vijeća Narodnog odbora općine Ivanec od 23. 12. 1958. godine: 17 .

98 Isto: 48

99 Veliki datum jugoslavenske trgovine, VA-MA, 28. prosinca 1972.: 6.

100 Isto.

101 KOŽAR 1986d.

102 Isto.

103 Veliki datum jugoslavenske trgovine, VA-MA, 28. prosinca 1972.: 6.
} 
nas ima i tako poštenih!“"104 Osoba potpisana kao „šjor bepo“ iz Splita je, pak, zapisala: „as ti gospu, ovako što nema u čitavoj Dalmaciji ni u Splitu, ovo je jedino na svitu.“105 „Do sada smo o vama samo slušali i čitali. Veseli nas da smo se danas s vama sreli i upoznali iskustva vašeg kolektiva koji je bio pionir u našoj republici na području bržeg i jednostavnijeg povezivanja trgovine i potrošača i na taj način unošenja kulturnijih i suvremenijih navika u život naših ljudi“", zapisale su 23. lipnja 1960. Marija Šoljan, Emilija Šeparović i Marija Erbežnik-Fuks iz Zagreba. ${ }^{106}$ Godine 1972. umirovljenik Stjepan Cesarec u jednom je intervjuu za Varaždinski magazin naglasio da je samoposluga stvarala povjerenje:

„Povjerenje koje je potrošačima ukazano kao da ih je moralno učvršćivalo. Bio je to istovremeno kulturni napredak i odgoj, čovjek je stvarao u sebi ličnost koja je imala pozitivan stav prema društvu. A to je bila velika stvar." ${ }^{107}$

Iako su novine pratile osnivanje prve samoposluge u Jugoslaviji, nisu bile ažurne u tome od njezinoga osnutka. Prve su o samoposluzi izvijestile lokalne novine Varaždinske vijesti, donijevši tek šturu obavijest da je trgovačko poduzeće „Ivanečki magazin“ otvorilo „ovih dana prodavaonicu kućnih potrepština, u kojoj se kupci sami poslužuju“ te da prodavaonica ima dobar promet. ${ }^{108}$ Nakon Varaždinskih vijesti krenuo je čitav niz izvješća o samoposluzi. Čak je i beogradska $B o r b a^{109}$ donijela izvješće o tome što se u Ivancu dogodilo krajem 1956. godine:

„Početak nije bio lak. Trebalo je najprije osigurati robu. I to ne običnu, već pomalo atraktivnu, ono što će građane privući da dođu do 'neobične radnje', koja je, osim toga što nije pružala prilike dokonim mušterijama, da se o svemu i svačemu napričaju dok prodavač nešto mjeri i pakuje, bila i prilično udaljena..." 110

Upravo je članak koji je donijela Borba dao naslutiti ono što je Katherine Verdery zaključila pišući o socijalizmu i robi koju pruža - on je davao samo ono najosnovnije, hranu i odjeću, a na sve je ostalo trebalo čekati. ${ }^{111}$ Zbog toga je i samoposluga u Ivancu bila tim veća atrakcija jer je donijela i mnoštvo robe koja se nije mogla naći u običnim trgovinama.

\footnotetext{
104 KOŽAR 1986d.

105 Veliki datum jugoslavenske trgovine, VA-MA, 28. prosinca 1972.: 6.

106 KOŽAR 1986d: 5.

107 Ispit poštenja, $V A-M A, 20$. prosinca 1972.: 7.

108 Varaždinske vijesti, 27. prosinca 1956.: 3.

109 Do 1954. Borba je bila službeno glasilo Saveza komunista Jugoslavije, a od te godine službeni organ Socijalističkog saveza radnog naroda Jugoslavije.

110 „Tihe prodaje“ u Ivanecu, Borba, 15. prosinca 1957.: 9.

111 VERDERI 2005: 54-55.
} 
Najopsežnije izvješće, uz slikovni materijal, donio je Večernji vjesnik, uz donekle senzacionalni naslov: „O onome što Zagreb nema, a selo Ivanec ima“. ${ }^{112} \mathrm{U}$ tom se napisu naglašava da je prije otvaranja samoposluge bilo raznih previranja $\mathrm{i}$ otpora, ali da su već prvi dani prodaje dokazali kako tome nije bilo mjesta. Nadalje se donosi informacija da se počelo skromno, s malenim brojem prehrambenih artikala, te da su nakon toga i sami kupci tražili proširenje asortimana, što je dovelo do povećanja prometa i prihoda. Ispod tih informacija našla se fotografija kupca i prodavača za blagajnom (Slika 5).

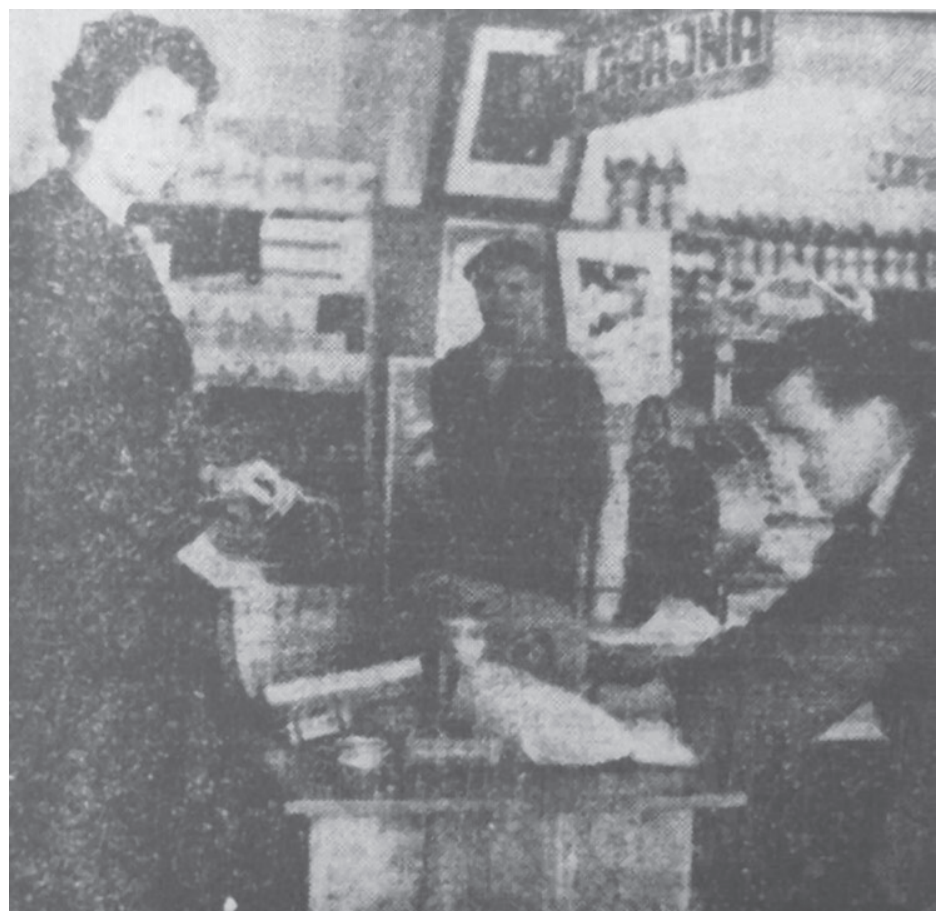

Slika 5: Kupac i prodavač u samoposluzi ${ }^{13}$

Autora je članka najviše fascinirala činjenica da je blagajnik jedini službenik s kojim se kupci susreću. Osoblje ove prodavaonice bilo je minimalno, iako je prodavaonica bila otvorena od 7 do $21 \mathrm{~h}$. Dvojica djelatnika izmjenjivala su se na blagajni, dok je treći pripremao i pakirao proizvode za prodaju. ${ }^{114}$ Članak je sadržavao i fotografiju samoposluge.

\footnotetext{
$\overline{112}$ O onome što Zagreb nema, a selo Ivanec ima, Večernji vjesnik, 30. rujna 1957.: 5.

113 Isto.

114 Isto.
} 


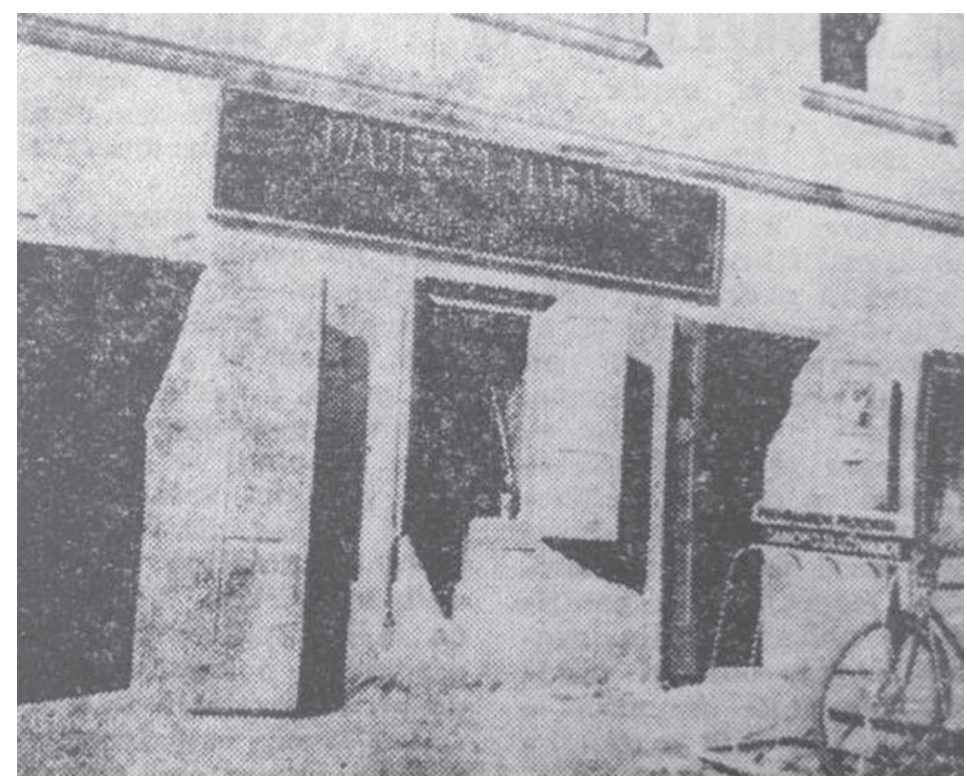

Slika 6: „Ivanečki magazin“115

O uspjehu samoposluge govorilo se i na raznim predavanjima ili skupovima. $\mathrm{Na}$ jednom takvom, 13. prosinca 1972. godine, na Visokoj školi za vanjsku trgovinu u Zagrebu predavanje studentima o prvoj samoposluzi u Ivancu održao je Andrija Sever. ${ }^{116}$ Uz njega su na predavanju bili i Stjepan Putarek kao komercijalni direktor samoposluge, zatim Rajka Zečević koja je pedesetih bila tajnik Trgovinske komore NR Hrvatske te Josip Kovačić, direktor „Konzuma“. ${ }^{117}$ Među navedenim predavačima našao se i dr. Krešimir Car, koji je 1957. napisao prvu knjigu o samoposlugama koja je objavljena u Jugoslaviji, i to samo pola godine nakon otvaranja prvog samoposluživanja u Ivancu. ${ }^{118}$ Ivanečki slučaj predstavlja iznimku u uobičajenoj praksi, prema kojoj uvođenju samoposluživanja prethodi pisanje o ideji i načinu na koji samoposluge trebaju izgledati i funkcionirati. Tek će 1959. godine Radničko sveučilište „Moša Pijade“ obrazovnu djelatnost proširiti i na područje trgovine te početi s izdavanjem priručnika za obrazovanje kadrova zaposlenih u trgovini. U sklopu toga je 1961. objavljen i prvi priručnik za opremanje i rad u samoposluživanju, koji je napisao Mirko Sagrak. ${ }^{119}$

\footnotetext{
115 Isto.

116 Veliki datum jugoslavenske trgovine, VA-MA, 28. prosinca 1972.: 6-7.

117 Isto.

118 CAR 1957.

119 SAGRAK 1961.
} 
Koliku je važnost imala pojava ivanečke samoposluge u tadašnjoj Jugoslaviji teško je jednoznačno odrediti. Podatak da je u Ivancu bila otvorena prva samoposluga u Jugoslaviji zasigurno jest imao odjeka, ne samo u čestim posjetima tadašnjih za novi oblik trgovanja zainteresiranih građana Jugoslavije. Ivanečka je samoposluga svojim kupcima pružala novi, dotad nepoznati doživljaj slobode u kupovini jer su oni prilikom boravka u samoposluzi sami uzimali ono što su trebali i na svojevrstan način, došavši u direktan kontakt s proizvodima na policama, otkrivali potpuno novi pogled na kupnju. Stanovnici Ivanca, kao i ostali kupci samoposluge, držali su je svojevrsnom atrakcijom. Postavši dio novog koncepta trgovine, građani Ivanca su, iako nesvjesno, među prvima započeli proces stvaranja potrošačkog društva u Hrvatskoj, a time i u čitavoj Jugoslaviji.

\section{Prva putujuća samoposluga u Jugoslaviji}

Kreativnost i inovativnost Severa i Putareka te njihova spremnost da provedu svoje ideje u stvarnost nije se zaustavila samo na samoposluzi. Na njihovu inicijativu 1958. godine radnički savjet poduzeća „Ivanečki magazin“ na svojoj je sjednici od 28. veljače donio odluku da se za potrebe poduzeća izvrši nabava teretnog automobila marke „TAM“ (Tvornica automobila Maribor) nosivosti triju tona. ${ }^{120}$ Budući da poduzeće za tu investiciju nije imalo vlastitih sredstava, odlučilo je zatražiti kredit iz općinskog investicijskog fonda, koji mu je i odobrio kredit u iznosu od 2,440.000 dinara. ${ }^{121}$ Upravo ovaj kredit i rasprava o kupnji vozila predstavljaju početak prve putujuće samoposluge u Jugoslaviji. Radnički je savjet „Ivanečkog magazina“ 16. srpnja 1962. godine donio odluku da se uvede putujuća samoposluga, koja je i otvorena 10. veljače 1963. godine. U „TAM“-u je nabavljeno specijalno vozilo koje je stajalo tadašnjih 10 milijuna dinara te je preuređeno u putujuću samoposlugu. ${ }^{122} \mathrm{Uz}$ vozača se u vozilu nalazio i blagajnik, koji je usput obnašao i dužnost poslovođe. Prvi vozač putujuće prodavaonice bio je Ivan Sever, a prvi poslovođa, odnosno blagajnik Ivan Posavi. ${ }^{123}$ Putujuća samoposluga nosila je oko dviju tona robe u asortimanu od oko dvjesto artikala za domaćinstvo. ${ }^{124}$

120 DAVŽ, 35, Narodni odbor kotara Varaždin, 1.2.2.4. Zapisnici sjednica. NOO Ivanec 1959., Zapisnik narodnog odbora općine Ivanec od 24. travnja 1959. godine: 10.

121 Isto.

122 Prva naša putujuća samoposluga, VA-MA, 7. ožujka 1973.: 7.

123 Isto.

124 Isto. 


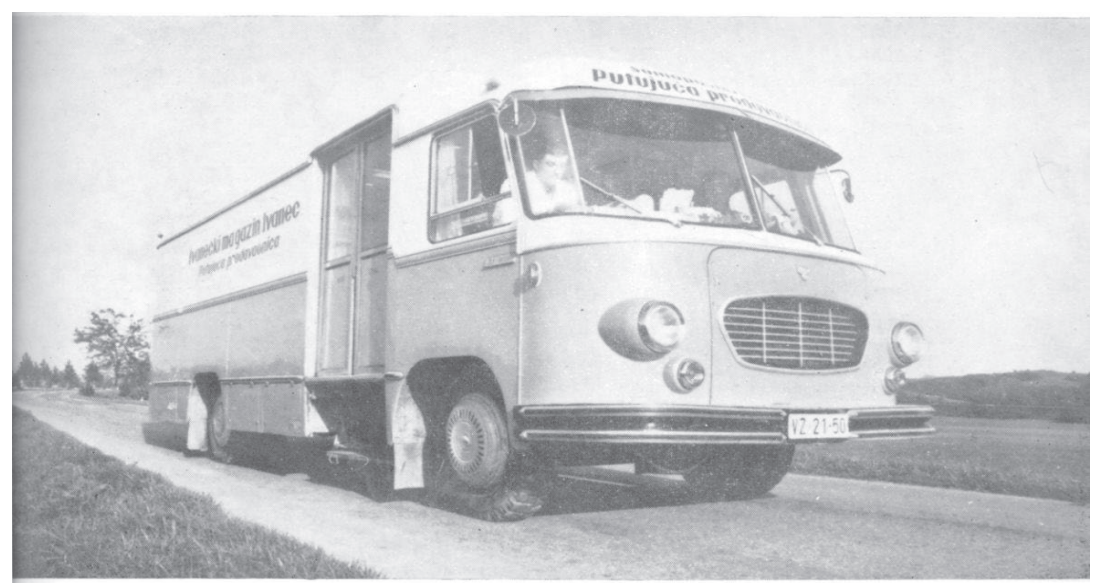

Slika 7: Prva putujuća samoposluga 1963. ${ }^{125}$

Na ideju o njezinu otvaranju Sever i Putarek došli su nakon što su ustanovili da postoje velike poteškoće u snabdijevanju seoskog stanovništva robom široke potrošnje. S tim u vezi proširen je asortiman robe te su stvoreni uvjeti za privikavanje seoskog stanovništva na potrošnju proizvoda koje inače nisu mogli nabaviti u standardnim seoskim prodavaonicama. ${ }^{126}$ Putujućom prodavaonicom omogućavala se kupnja i onim ljudima koji su živjeli relativno daleko od bilo kakvih trgovina. Ti su ljudi dobili komfor tako da su im se namirnice gotovo dostavljale na kućni prag. Isto tako, roba se svakodnevno mijenjala i bila je svježa, za razliku od stacionarnih prodavaonica u zaseocima, $\mathrm{u}$ kojima se roba nije dostavljala svakodnevno. ${ }^{127}$ Može se reći da je putujuća prodavaonica u tom vremenu bila blagodat za seosko stanovništvo. Važno je napomenuti da se naglašavala i činjenica da se putujućom samoposlugom roba intenzivno prodavala jer su se kupci okupljali u određeno vrijeme, što je omogućavalo visoku radnu produktivnost osoblja, a što je i službena državna politika propagirala u svakoj prilici.

U početku je dnevna relacija putujuće samoposluge iznosila ukupno $42 \mathrm{~km}$, unutar kojih bi prodavaonica stala na devet stajališta. Radno vrijeme na stajalištima bilo je točno određeno, a iznosilo je između 25 i 40 minuta, ovisno o naseljenosti, blizini drugih trgovina te preferencijama samih potrošača. Ukupno bi u jednom radnom danu dva sata otpalo na vožnju, pet sati na prodaju te jedan sat na pripreme. Predviđenoj relaciji gravitiralo je desetak sela (Bedenec Gornji, Bedenec Donji, Belšćak, Ivanec Gornji, Ivanečki Vrhovec, Kaniža, Lančić, Punikve, Salinovec, Višnjica, Voća i Voća Rijeka) i više zaselaka s oko 1.000 domaćinstava i oko 5.000

$\overline{125}$ Suvremeno trgovanje u Ivancu, Ivanečki kalendar 1974: 25.

126 Prva naša putujuća samoposluga, VA-MA, 7. ožujka 1973.: 7.

127 Isto. 
stanovnika. ${ }^{128}$ Trasa se s vremenom mijenjala jer su se otvarale i nove prodavaonice, a putujuća prodavaonica išla je samo na ona mjesta gdje prodavaonica nije bilo. S vremenom se relacija na kojoj je djelovala smanjivala, tako da je 1973. godine samoposluga vozila tek na relaciji od 22 kilometra s postajama Bedenec, Gornji Bedenec, Donji Bedenec, Lančić, Punikve, Ivanečki Vrhovec i Gornji Ivanec, a dotad je vozilo prešlo preko 120.000 kilometara. ${ }^{129}$

U prvoj godini rada putujuća samoposluga ostvarila je promet od oko $80 \mathrm{mi}-$ lijuna dinara (starih), a idućih se godina taj promet kretao od 80 do 100 milijuna dinara. Godine 1972. promet je premašivao čak 100 milijuna dinara, unatoč skraćenju rute. ${ }^{130}$

Kao što je ivanečka samoposluga nekad kao prva trgovina takve vrste privlačila ljude iz svih krajeva Jugoslavije, i prva putujuća samoposluga bila je svojevrsna atrakcija te je 1963. godine sudjelovala u prvosvibanjskoj paradi u Beogradu. ${ }^{131}$

Prije uvođenja putujuće samoposluge, 6 . srpnja 1962. godine među stanovnicima mjesta provedena je anketa o tome kakve su njihove potrebe, žele li uvođenje putujuće prodavaonice, hoće li u njoj kupovati i kolika je količina i vrsta robe potrebna u zaseocima. Taj podatak govori da su ondašnji trgovci bili svjesni osnovnog ekonomskog zakona ponude i potražnje te da su zbog toga izvršili ono što se naziva ispitivanjem tržišta. Iako anketa nije sačuvana u arhivskim materijalima, u Varaždinskome magazinu ostaju uglavnom pozitivni dojmovi ljudi kojima je putujuća samoposluga, pogotovo na selu, uvelike olakšala svakodnevicu, a poduzeću „Ivanečkog magazina“ povećala rentabilnost. Dok je za Josipa Kuštera iz Ivanečkog Vrhovca putujuća samoposluga predstavljala „zlatnu stvar“ koju su dočekivali svakodnevno i koja ih je spasila od pješačenja, Đurđica Maloić i Đurđica Komes iz Punikvi zamjerale su putujućoj samoposluzi slab asortiman proizvoda, navodeći da nekad nema dovoljno piva ni deterdženta te da bi trebalo dopremiti kekse „Albert“ $i$ šire rezance. ${ }^{132}$

Podatak da su neki kupci negodovali zbog nedostatka mesa i nekih drugih gotovih prehrambenih proizvoda u putujućoj samoposluzi pokazuje da je potrošačka kultura utjecala i na svakodnevni život seljaštva. Seljaštvo koje je tradicionalno vezano za poljoprivredu i stočarstvo te koje je dotad uglavnom samo sebi proizvodilo hranu i zadovoljavalo većinu svojih potreba ${ }^{133}$ počelo se sve više privikavati na gotovu industrijsku hranu i gotove proizvode.

\footnotetext{
128 Suvremeno trgovanje u Ivancu, Ivanečki kalendar 1974: 25-26.

129 Prva naša putujuća samoposluga, VA-MA, 7. ožujka 1973.: 7.

130 Isto.

131 Isto.

132 Isto.

133 PULJIZ 1970: 23.
} 


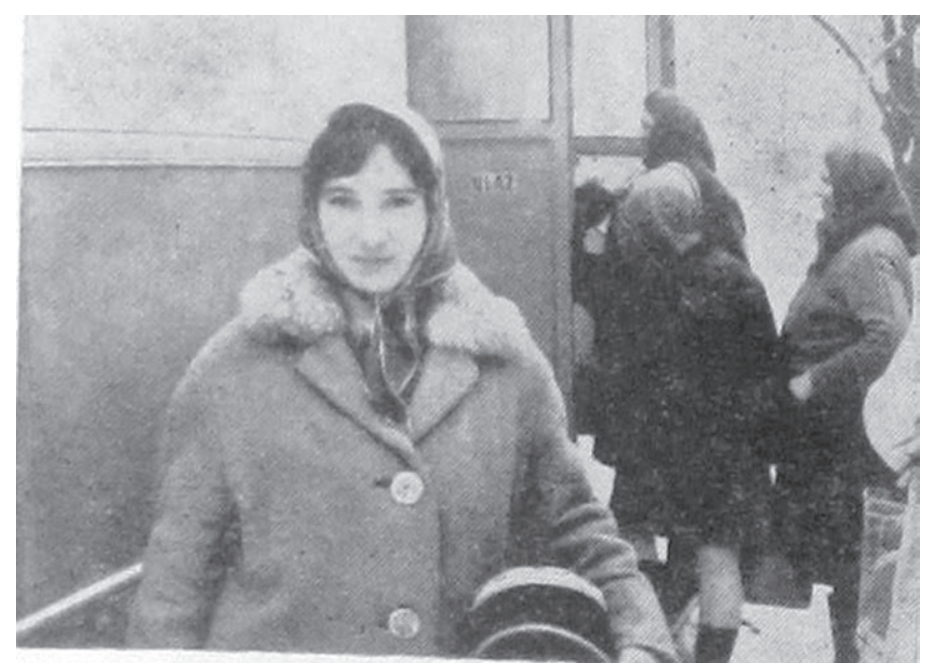

Slika 8: Kupci ulaze u putujuću samoposlugu 1973. ${ }^{134}$

\section{Društveno-ekonomske promjene i ivanečka trgovina}

U prvim dvama desetljećima poslijeratne Jugoslavije došlo je do svojevrsnog raspada dotadašnjega tradicionalnoga agrarnoga društva. Promjena ekonomske strukture stanovnika Jugoslavije bila je intenzivna kao u rijetko kojoj drugoj zemlji svijeta. Dok je 1945. godine poljoprivredno stanovništvo činilo oko 75 \% ukupne populacije, njegov je udio do 1965 . godine smanjen na oko $46 \%$. ${ }^{135}$ Prijelaz poljoprivrednika u nepoljoprivredne djelatnosti sa sobom je nosio posljedice u svim sferama života na selu. Na selu je opao natalitet i prirodni priraštaj, promijenila se opća i obrazovna struktura stanovništva, kao i ishrana, higijena, zdravstvo, običaji i navike, a značajno su drugačiji postali i njihovi stavovi prema zemlji, proizvodnji i potrošnji. ${ }^{136}$ Može se ustvrditi da su se na selu značajno izmijenili ekonomski odnosi jer u njega prodiru novi oblici poduzetništva i noviji načini korištenja ruralnim prostorom. Osim što je na selu donosio promjene socijalne strukture, proces deagrarizacije značajno je utjecao i na čitavo društvo.

Procesom deagrarizacije i deruralizacije bilo je zahvaćeno i područje Ivanca upravo od sredine 1950-ih, a bilo je međuovisno o procesu industrijalizacije i urbanizacije. Veće urbane sredine, prvenstveno Varaždin i Zagreb, privlačile su stanovništvo Ivanca, koje je sve više migriralo prema urbanim centrima. ${ }^{137}$ Po-

\footnotetext{
134 Prva naša putujuća samoposluga, VA-MA, 7. ožujka 1973.: 7.

135 MARKOVIĆ 1968: 77.

136 LIVADA 1969: 4.

137 FELETAR 1997: 91.
} 
ljoprivredno stanovništvo Općine Ivanec, kao i stanovništvo u ukupnom broju, konstantno je opadalo od sredine 1950-ih (Tablica 1). Općina je 1953. imala ukupno 52.541 stanovnika, a od 22.556 radno aktivnih stanovnika, $76 \%$ činilo je poljoprivredno stanovništvo. Godine 1961. ukupan broj stanovnika pao je na 49.222, od čega je bilo 29.090 aktivnih stanovnika, a od toga je poljoprivredno stanovništvo činilo 60 \%. Taj negativni trend nastavio se i u 1970-im godinama, tako da je 1971. godine ukupni broj stanovnika pao na 46.360, a od 25.452 radno aktivna stanovnika, njih $59 \%$ bilo je poljoprivredno.

Tablica 1: Udio stanovništva u poljoprivrednoj i nepoljoprivrednoj djelatnosti ${ }^{138}$

\begin{tabular}{|c|c|c|c|c|c|c|}
\hline Godina & $\begin{array}{c}\text { Ukupno } \\
\text { stanovništvo u } \\
\text { Općini Ivanec }\end{array}$ & $\begin{array}{c}\text { Ukupno } \\
\text { aktivno } \\
\text { stanovništvo }\end{array}$ & $\begin{array}{c}\text { Aktivno } \\
\text { stanovništvo u } \\
\text { poljoprivredi }\end{array}$ & $\%$ & $\begin{array}{c}\text { Aktivno } \\
\text { stanovništvo u } \\
\text { nepoljoprivrednim } \\
\text { djelatnostima }\end{array}$ & $\%$ \\
\hline 1953. & 52.541 & 22.556 & 17.222 & 76 & 5.334 & 24 \\
\hline 1958. & - & 20.499 & 15.551 & 76 & 4.948 & 24 \\
\hline 1961. & 49.222 & 29.090 & 17.365 & 60 & 11.725 & 40 \\
\hline 1971. & 46.460 & 25.452 & 15.138 & 59 & 10.314 & 41 \\
\hline
\end{tabular}

Unatoč deruralizaciji i smanjenju ivanečkog stanovništva, trgovinska je aktivnost općine uglavnom rasla, što je vidljivo i na primjeru poduzeća IMA. U razdoblju od 1947. do 1972. broj prodavaonica u sklopu IMA-e kretao se između 11 i 29 (isključujuću prvu, 1947. godinu, kad je poduzeće tek nastalo i tad imalo 3 prodavaonice). Najveći je porast broja prodavaonica IMA imala 1959. godine, kad se broj sa šesnaest (iz 1958.) penje na 29.

Što se tiče broja zaposlenih, on je ipak rastao puno brže od broja prodavaonica. Od prve godine, kad je broj zaposlenih bio tek 37, već 1949. godine IMA broji 72 zaposlenika. Međutim, tijekom pedesetih broj zaposlenika oscilira i generalno pada, a iznosio je manje od 60 zaposlenika. Od 1960. broj se zaposlenika ponovno povećava iznad 60, a vrhunac je dostigao 1971. (140), ponajviše zbog toga što je 3. travnja te godine otvorena i robna kuća IMA, koja je zapošljavala veći broj ljudi. Godine 1972. došlo je do drastičnog smanjenja broja zaposnika sa 140 na 99.

138 VRČEK 1979: 10-11. 


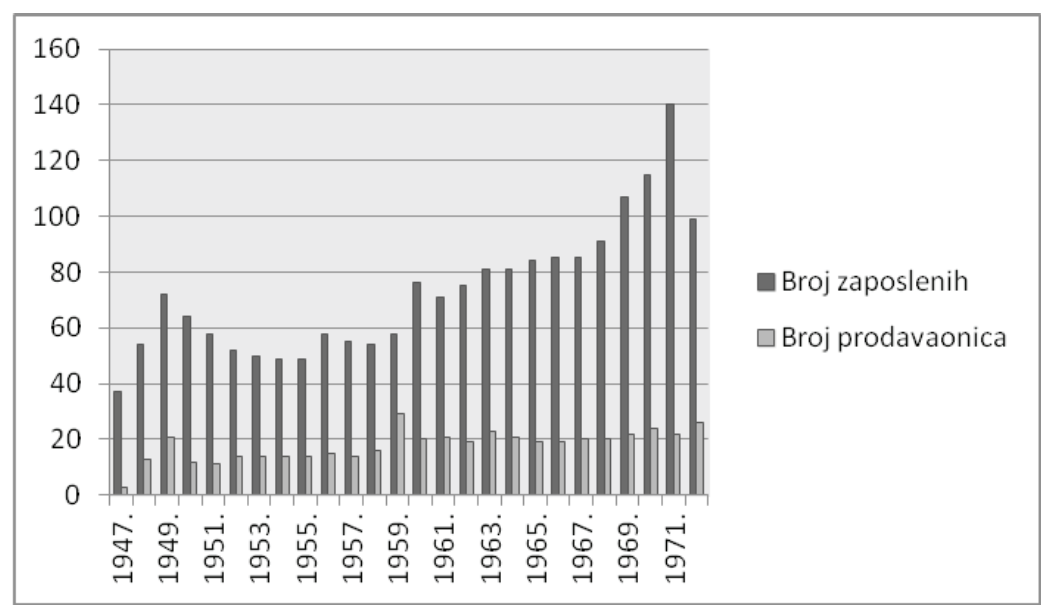

Grafikon 1: Broj zaposlenih i broj prodavaonica u IMA-i od 1947. do 1972. ${ }^{139}$

Zaposlenici su donosili značajan profit svojim prodavaonicama, a zarada je s godinama, unatoč povremenim oscilacijama broja radnika ili broja prodavaonica, eksponencijalno rasla. Tek je 1957. godina bila iznimka. Tada je profit bio nezamjetno manji nego 1956. godine. Godine 1972., kojom i završava naša analiza, ukupni promet IMA-e iznosio je dotad najviših 62,537.000 novih dinara. ${ }^{140}$

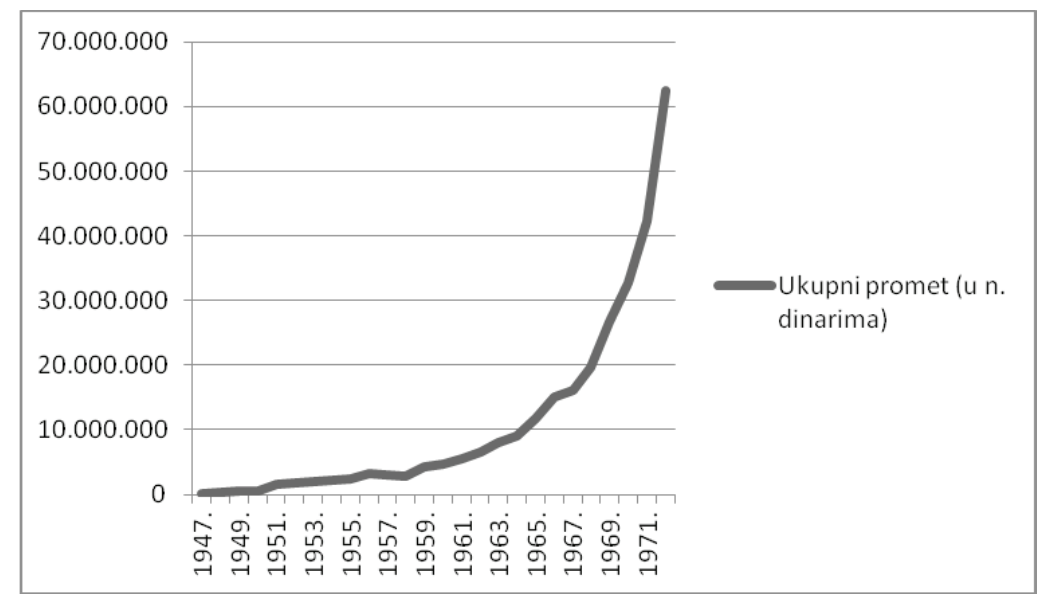

Grafikon 2: Ukupni promet IMA-e u dinarima 1947. - 1972. ${ }^{141}$

139 Grafikon izrađen na temelju podataka iz članka Suvremeno trgovanje u Ivancu, Ivanečki kalendar 1974: 26.

140 Važno je napomenuti da je 1. siječnja 1966. dinar SFRJ denominiran za dva decimalna mjesta te se mijenjao u omjeru 1 novi dinar za 100 starih dinara.

141 Grafikon izrađen na temelju podataka iz članka Suvremeno trgovanje u Ivancu, Ivanečki kalendar 1974: 26. 
Navedene su brojke, unatoč padu broja zaposlenika, svjedočile o razvitku kulture samoposluživanja i pokazale da je došlo do rasta kupovne moći zbog ekonomskog napretka jugoslavenskoga gospodarstva, što se reflektiralo i na lokalne zajednice poput Ivanca.

\section{Zaključak}

Samoposluživanje je kao oblik trgovanja bilo vezano prvenstveno za kapitalističke zemlje sve do sredine 1950-ih godina, kada se počinje javljati i u onim socijalističkima. Među prvim socijalističkim zemljama u kojima se javio taj oblik trgovanja bila je Jugoslavija. Dopuštanje, štoviše i poticanje samoposlužnoga oblika trgovine, što je predstavljalo jedan od segmenata procesa amerikanizacije, uklapa se u dosadašnje spoznaje o Jugoslaviji kao o socijalističkoj državi otvorenijoj utjecajima Zapada od ostalih socijalističkih zemalja Europe. Dopuštanjem i poticanjem tog trgovinskog oblika socijalistička Jugoslavija težila je pokazati da je jugoslavenska ekonomija fleksibilnija i otvorenija za inovacije i nove ideje.

Prva je jugoslavenska, a ujedno i prva samoposluga u Jugoistočnoj Europi otvorena krajem 1956. godine u mjestu Ivancu, koje je time postalo svojevrsnom malom turističkom atrakcijom za građane koji su povremeno u skupinama dolazili iz raznih dijelova Jugoslavije, ali i poticajem za otvaranje novih samoposluga, koje su se u idućih nekoliko godina pojavile po cijeloj Jugoslaviji. Ivanečki poduzetnici ovdje nisu stali sa svojim inovacijama jer su već 1958. godine pokrenuli inicijativu za otvaranjem prve putujuće samoposluge, koja je i započela s radom 1963. godine.

Već na prvi pogled iznenađuje činjenica da se prva samoposluga otvara u jednome manjem mjestu, a ne u nekom velikom urbanom središtu poput Beograda, Zagreba ili Ljubljane. Pitanje je zašto se upravo u Ivancu otvorila prva samoposluga i prva putujuća samoposluga, a prema nekim izvorima i jedan od prvih OOUR-a u trgovinskom sektoru. ${ }^{142}$ Početkom 1970-ih tadašnji direktor opće i kadrovske službe „Varaždinskog magazina“ Josip Sudec navodio je da se to nije dogodilo slučajno, već zato što je „tradicija trgovine u Ivancu veoma bogata“. ${ }^{143}$

Je li se uistinu radilo o ambicioznom pothvatu dvojice poduzetnih trgovaca (Severa i Putareka) ili se, pak, radilo o potezu smišljenom na nekim višim političkim instancijama, koje su takav eksperiment odlučile najprije primijeniti u nekoj manjoj sredini te potom vidjeti može li se takav koncept primijeniti i šire. Nije nemoguća pretpostavka da se radilo o političkom nalogu za njezinim otvaranjem

\footnotetext{
142 Prema glasilu poduzeća „Varaždinski magazin“, u Ivancu je osnovan jedan od prvih OOUR-a u sektoru trgovine u čitavoj Jugoslaviji. Naime, 19. travnja 1972. donesena je odluka o formiranju OOUR-a „IMA“ Ivanec, koje je bilo dio poduzeća „Varaždinski magazin“. PUHALOVIĆ 1972: 1.

143 Formirana prva organizacija udruženog rada „IMA“ - Ivanec, VA-MA, 15. rujna 1972.: 2.
} 
$\mathrm{u}$ tako malome mjestu poput Ivanca s intencijom da u slučaju propasti eksperimentalnog projekta samoposluge ne bude većeg odjeka, niti posljedica za imidž jugoslavenskoga ekonomskoga sustava. Pogotovo je to moguće kad se ima na umu tadašnje partijski zadane ekonomske okvire u kojima nije bilo previše mjesta

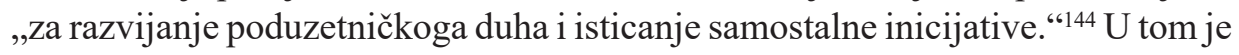
smislu zanimljiv komentar Ignaca Puhalovića, nekadašnjega generalnog direktora poduzeća „Varaždinski magazin“, koji je 1975. godine govorio da je Ivanec odabran jer se radilo o progresivnim ljudima, „Kadrovima, koji su se posvetili razvoju trgovine, koji su dobro ocijenili svoje mogućnosti i potrebe svojih potrošača.“145 Puhalović je i u svome govoru iz 1972. godine nakon formiranja OOUR-a IMAe naglasio da Varaždinski magazin ,prati i sprovodi politiku druga Tita i našeg centralnog komiteta SKJ, da se bori za samoupravne socijalističke odnose“. ${ }^{146}$

Ipak, u Državnom arhivu u Varaždinu, u kojem se nalazi građa ivanečkih narodnih odbora, kao i građa drugih relevantnih institucija varaždinskoga kraja iz druge polovine 1950-ih, nismo našli dokument koji bi potvrdio tezu da je otvaranje prve samoposluge bilo smišljeno na nekim višim političkim instancijama. To je jedan od razloga zbog kojeg smatramo da otvaranje samoposluge u Ivancu nije imalo takvu političku težinu da bi se o tome posebno raspravljalo na visokim državnim i partijskim forumima. Bliže smo zaključku da se radilo o poklapanju nekoliko važnih inicijativa. Prva jest ta da je jugoslavenski državni vrh već u prvoj polovini 1950-ih napravio politički zaokret koji je podrazumijevao odmak od sovjetskoga modela i poboljšanje odnosa s kapitalističkim zemljama. U skladu s time učinjen je i ekonomski zaokret u formi radničkog samoupravljanja kojim je jugoslavenska ekonomija postala ipak otvorenija za principe koji su bili svojstveni kapitalističkim ekonomijama. Gostovanja američkih poduzetnika u Jugoslaviji i njihovo propagiranje samoposluživanja ne bi se moglo dogoditi da jugoslavenska visoka politika nije napravila takav zaokret. Upravo je na jednom takvom predavanju u glavama dvojice ivanečkih trgovaca i nastala ideja o prvome samoposluživanju.

Otvaranje prve samoposluge u Ivancu bio je jedan protokorak u pojavi i širenju koncepta samoposluživanja, nezavisan o političkom vrhu, što dokazuje i činjenica da je plan o razvoju samoposluga SIV donio tek nakon uspješne promocije američke samoposluge na Zagrebačkom velesajmu 1957. godine. Indikativno je da je jugoslavenski vrh prihvatio dotad uglavnom kapitalističku pojavu, što potvrđuje uvriježenu interpretaciju da je Jugoslavija „manevrirala“ između Istočnoga i Zapadnoga bloka, preuzimajući vrijednosti jednog i drugoga i implementirajući ih u svoj sustav na specifičan način.

144 DOBRIVOJEVIĆ 2013: 35.

145 KOŽAR 1976: 1.

146 PUHALOVIĆ 1972: 1. 
Radina Vučetić smatra da je pojava samoposluga bila vezana uglavnom za proces amerikanizacije, kojem je Jugoslavija bila izložena prvenstveno zbog jakih političkih i kulturnih veza sa SAD-om i na osnovi čega je američka svakodnevica u mnogočemu postala i jugoslavenska realnost. ${ }^{147}$ Zaista, kada se govori o razvoju i širenju tog koncepta trgovine, možemo se složiti da se radilo o procesu koji je promovirala i afirmirala jugoslavenska vlast, kao i oko tvrdnje da je riječ o jednom dijelu procesa amerikanizacije Jugoslavije. Ipak, ideja dvojice ivanečkih trgovaca došla je prije tih direktnih političkih odluka i izraz je poduzetničkog duha tih ljudi, koji su, svjesni ili ne da primjenjuju temeljni ekonomski postulat kapitalističkog sustava - zakon ponude i potražnje - osluškivali želje tržišta i trudili se tržištu neprestano nuditi nešto novo.

Prema Igoru Dudi, jugoslavensko je društvo 1960-ih postalo potrošačko, a u tome je značajan segment bila upravo pojava samoposluživanja. ${ }^{148}$ Tomu u pri$\log$ ide i ovo istraživanje koje je donekle prikazalo kako se taj proces odvijao u lokalnoj sredini. I ivanečka samoposluga, kao i ona putujuća, polako su mijenjale način života seoskoga stanovništva koje se sve više okretalo kupnji industrijskih proizvoda, pa čak i gotove hrane koju su dotad uglavnom sami proizvodili. Pojava samoposluge stanovnicima Ivanca pružila je dotad nepoznati oblik trgovine i doživljaj kupovanja karakterističan ponajprije za kapitalistička potrošačka društva. Kupci su dobili određeni osjećaj slobode prilikom kupovine jer su se u prodavaonici mogli slobodno kretati te su imali mogućnost slobodnog izbora. Putujuća je samoposluga proizvode široke potrošnje učinila dostupnima i onim stanovnicima, prvenstveno seljacima, koji nisu živjeli blizu samoposluge. Potrošnja je tako postajala masovnijom jer su ljudi na više mjesta dobili mogućnost pristupa sve raznovrsnijem proizvodnom asortimanu. Ivanečko samoposluživanje i putujuća prodavaonica bili su značajan segment razvoja potrošačkog društva i modernizacije na prostoru ivanečke općine, koja je neplanirano odigrala ulogu eksperimentalne lokacije jugoslavenske samoposlužne trgovine.

147 VUČETIĆ 2012: 282.

148 DUDA 2005: 145. 


\section{Bibliografija}

\section{Arhivski izvori}

Državni arhiv u Varaždinu. Narodni odbor kotara Varaždin.

Narodni odbor kotara Varaždin. Arhinet - Hrvatski državni arhiv. http://arhinet.arhiv.hr/ details.aspx?ItemId=3_13268 (posjet 12. 4. 2016).

Državna geodetska uprava. Katastar grada Ivanca, gruntovnica. Zemljišno-knjižni uložak 17.

\section{Objavljeni izvori}

VII kongres Saveza komunista Jugoslavije. 1958. Beograd: Kultura.

BROZ TITO, Josip. 1959. Govori i članci: 30. XI. 1954. - 31. I. 1956. Zagreb: Naprijed.

BROZ TITO, Josip. 1976. Tito o privredi 1945-1975. Beograd: Privredni pregled.

\section{Novine}

Borba, 1957.

Ivanečki kalendar, 1974., 1979.

VRČEK, Vinko. 1979. Osvrt na privredni razvoj općine Ivanec od 1945. do 1975. godine. Ivanečki kalendar 1979: 8-15.

Ivanečke novine, 2009.

KUŠEN, Eduard. 2009. Zgrada prvog samoposluživanja čeka obnovu i spomeničku namjenu. Ivanečke novine, 30. lipnja 2009.: 14-15.

VA-MA: Informativni list radne zajednice Varaždinskog magazina, 1972. - 1973.

PUHALOVIĆ, Ignac. 1972. Ustavni amandmani u praksi - najdraža radna pobjeda. VAMA: Informativni list Radne zajednice Varaždinskog magazina 2/4: 1.

Varaždinske vijesti, 1956., 1986.

KOŽAR, Boris. 1986a. Pionirski pothvat Ivanečkih trgovaca: Prije tri desetljeća (1). Varaždinske vijesti, 11. rujna 1986.: 5.

KOŽAR, Boris. 1986b. Pionirski pothvat Ivanečkih trgovaca: Prije tri desetljeća (2). Varaždinske vijesti, 18. rujna 1986.: 5.

KOŽAR, Boris. 1986c. Pionirski pothvat Ivanečkih trgovaca: Prije tri desetljeća (4). Varaždinske vijesti, 2. listopada 1986.: 5.

KOŽAR, Boris. 1986d. Pionirski pothvat Ivanečkih trgovaca: Prije tri desetljeća (6).

Varaždinske vijesti, 16. listopada 1986.: 5.

Večernji vjesnik, 1957. 


\section{Literatura}

BEKIĆ, Darko. 1988. Jugoslavija u hladnom ratu: odnosi s velikim silama 1949-1955. Zagreb: Globus.

BENSON, John. 1994. The Rise of Consumer Society in Britain. 1880-1980. London \& New York: Longman.

BEREND, Iván T. 1996. Central and Eastern Europe, 1944 - 1993: Detour from the Periphery to the Periphery. Cambridge, New York: Cambridge University Press.

BILANDŽIĆ, Dušan. 1999. Hrvatska moderna povijest. Zagreb: Golden marketing.

CAR, Krešimir. 1957. Samoposluživanje u trgovini na malo. Beograd: Grafičko preduzeće "Grafika“.

Das Dokumentationszentrum Alltagskultur der DDR. 2006. Konsum: Konsumgenossenschaften in der DDR [Begleitbuch zur gleichnamigen Ausstellung im Dokumentationszentrum Alltagskultur der DDR, Eisenhüttenstadt, und der Neuen Kauffahrtei, Chemnitz]. Köln: Böhlau Verlag GmbH.

DE GRAZIA, Victoria. 2005. Irresistible Empire: Amreica's Advance through TwentiethCentury Europe. Cambridge, Mass.: Belknap Press of Harvard University Press.

DOBRIVOJEVIĆ, Ivana. 2013. Industrijalizacija kao imperativ. Ekonomska politika Partije 1945-1955. U Socijalizam na klupi: Jugoslavensko društvo očima nove postjugoslavenske humanistike, ur. Lada Duraković, Andrea Matošević, 17-45. Pula, Zagreb: Sveučilište Jurja Dobrile u Puli, Srednja Europa.

DUDA, Igor. 2003. Samoposluga kao vijest dana. Počeci suvremenog potrošačkog društva 1950-ih i 1960-ih godina. Problemi sjevernog Jadrana 8: 267-278.

DUDA, Igor. 2005. U potrazi za blagostanjem. O povijesti dokolice i potrošačkog društva u Hrvatskoj 1950-ih i 1960-ih. Zagreb: Srednja Europa.

DUDA, Igor. 2010. Pronađeno blagostanje. Svakodnevni život i potrošačka kultura u Hrvatskoj 1970-ih i 1980-ih. Zagreb: Srednja Europa.

FELETAR, Dragutin. 1997. Promjene u prostornoj slici naseljenosti ivanečkoga kraja. U Zbornik 600 godina Ivanca, 91-104. Varaždin: Hrvatska akademija znanosti i umjetnosti, Zavod za znanstveni rad.

Godine socijalističke izgradnje Općine Ivanec 1945.-1965. 1965. Ivanec: Općina Ivanec. GOLDSTEIN, Ivo. 2008. Hrvatska 1918.-2008. Zagreb: EPH, Novi liber.

HAMLET, Jane. 2008. Regulating UK supermarkets: an oral-history perspective. History and Policy. http://www.historyandpolicy.org/papers/policy-paper-70.html (posjet 15. 3. 2016).

HOBSBAWM, Eric. 2009. Doba ekstrema: kratko dvadeseto stoljeće 1914. - 1991. Zagreb: Zagrebačka naklada.

JAKOVINA, Tvrtko. 2003. Narodni kapitalizam protiv narodnih demokracija. Američki super-market na Zagrebačkom velesajmu 1957. godine. Zbornik Mire Kolar Dimitrijević, ur. Damir Agičić, 469-479. Zagreb: FF-press.

JESSEN, Ralph, Lydia LANGER. 2016. Introduction: Transformations of Retailing in Europe after 1945. U Transformations of Retailing in Europe after 1945, ur. Ralph Jessen, Lydia Langer, 1-18. London, New York: Routledge. 
JUDT, Tony. 2007. Postwar: a history of Europe since 1945. London: Pimlico.

KLOPPENBORG MADSEN, Erik. 2016. A History of Danish Advertising, Market Research, and Retailing: 1920-1960. U The Routledge Companion to Marketing History, ur. D. G. Brian Jones, Mark Tadajewski, 419-432. Basingstoke: Routledge.

KOŽAR, Boris (ur.). 1976. 20 godina prve jugoslavenske prodavaonice na principu samoposluživanja. Ivanec: IMA.

KUŠEN, Eduard. 2012. Trgovinska baština 55 godina samoposluživanja. Suvremena trgovina 37/2: 52-56.

LAMPE, John R. 1996. Yugoslavia as History: Twice there was a Country. New York: Cambridge University Press.

LIVADA, Svetozar. 1969. Promjene socijalno-ekonomske strukture poljoprivrede i sela u svjetlu novijih podataka. Sociologija sela 26: 3-12.

MARKOVIĆ, Petar. 1968. Uticaj profesionalne orijentacije seoske omladine na strukturne promene u poljoprivredi. Sociologija sela 22: 77-81.

MATICKA, Marijan. 1999. Opskrba stanovništva u Hrvatskoj od 1945. do 1953. godine. U Zbornik Mirjane Gross: u povodu 75. rođendana, ur. Neven Budak i dr., 387-401. Zagreb: Filozofski fakultet, Zavod za hrvatsku povijest.

MATKOVIĆ, Hrvoje. 2003. Povijest Jugoslavije (1918.-1991.-2003.). Zagreb: Naklada Pavičić.

NOVAK, Iva, Livia ČVELJO. 2009. Pola stoljeća samoposluživanja u Europi. Metro portal, 8. veljače 2008. http://metro-portal.hr/pola-stoljeca-samoposluzivanja-u-europi/2678 (posjet 14. 4. 2016).

PEROVIĆ, Latinka. 1991. Zatvaranje kruga: Ishod političkog rascjepa u SKJ 1971/1972. Sarajevo: Svjetlost.

PERSSON, Karl Gunnar. 2010. An Economic History of Europe: Knowledge, Institutions and Growth, 600 to the Present. New York: Cambridge University Press.

Piggly Wiggly: About us. http://www.pigglywiggly.com/about-us (posjet 13. 3. 2016).

PULJIZ, Vlado. 1970. Iseljavanje stanovništva iz sela i poljoprivrede (Nekoliko podataka i zapažanja). Sociologija sela 27-28: 14-26.

RADELIĆ, Zdenko. 2006. Hrvatska u Jugoslaviji 1945.-1991. Od zajedništva do razlaza. Zagreb: Školska knjiga, Hrvatski institut za povijest.

SAGRAK, Mirko. 1961. Mi i samoposluživanje. Zagreb: Radničko sveučilište „Moša Pijade“.

SCARPELLINI, Emanuela. 2004. Shopping American-Style: The Arrival of the Supermarket in Postwar Italy. Enterprise \& Society 5/4: 625-668.

SCARPELLINI, Emanuela. 2016. The Long Way to the Supermarket: Entrepreneurial Innovation and Adaptation in 1950s-1960s Italy. U Transformations of Retailing in Europe after 1945, ur. Ralph Jessen, Lydia Langer, 55-69. London, New York: Routledge.

STEARNS, Peter N. 1997. Stages of Consumerism: Recent Work on the Issues of Periodization. Journal of Modern History 69/1: 102-117. 
STIPETIĆ, Vladimir. 2012. Dva stoljeća razvoja hrvatskoga gospodarstva (1820.-2005.).

Zagreb: Hrvatska akademija znanosti i umjetnosti, Razred za društvene znanosti.

VACIĆ, Aleksandar M. 1989. Jugoslavija i Evropa: uporedna analiza privrednog razvoja Jugoslavije: 1971-1987. Beograd: Ekonomika.

VERDERI, Ketrin. 2005. Što je bio socijalizam i što dolazi posle njega. Beograd: Fabrika knjiga.

VOJNIĆ, Dragomir. 2008. Razvitak gospodarstva Hrvatske. U Titovo doba: Hrvatska prije, za vrijeme i poslije, ur. Tomislav Badovinac, 231-295. Zagreb: Savez društava „Josip Broz Tito“ Hrvatske.

VUČETIĆ, Radina. 2012a. Koka kola socijalizam. Amerikanizacija jugoslovenske popularne kulture šezdesetih godina XX veka. Beograd: Službeni glasnik.

VUČETIĆ, Radina. 2012b. Potrošačko društvo po američkom modelu (jedan pogled na jugoslavensku svakodnevicu šezdesetih). Časopis za suvremenu povijest 44/2: 277-298.

ZEGNAL, Sanja. 2006. Ivanec obilježava 50 godina samoposluge. Jutarnji list, 27. studenoga 2006. http://www.jutarnji.hr/ivanec-obiljezava-50-godina-samoposluge/164023/ (pristup 14. 4. 2016)

\section{Ivanec as an Experimental Location for a Yugoslav Self-Service Store}

In this article the two authors analyse and explain the context in which the first self-service store was opened in socialist Yugoslavia. By examining the context of its emergence, i.e. the Cold War and the somewhat "neutral" position of Yugoslavia, the authors explain the political and social circumstances in which the concept of self-service trade emerged in socialist Yugoslavia. This article traces the development of the self-service concept and its impact on the socio-economic changes at the local level, since the mid-1950s to the early 1970s. The research is based on various archival materials, Yugoslav newspapers from that period, as well as on the analysis of the local newspapers Varaždinski magazin which was published by the Trading Company "Ivanečki magazin". Despite the fact that the concept of self-service store was conceived and implemented by the state authorities in 1957, this article shows that the beginnings of the self-service concept were in fact related to and implemented as a result of the enterprising initiative of individuals. As this article shows, the first self-service store in socialist Yugoslavia was opened in 1956 in the small town of Ivanec, near the city of Varaždin in northern Croatia. The store was opened as an integral part of the Trading Company "Ivanečki magazin". Another interesting fact presented in this article is that the first mobile self-service store in socialist Yugoslavia was also established by individual initiative in this small town. In the end, the two authors show how in a one-party state, private initiative was able to bring changes on national level. 
Keywords: self-service store, Yugoslavia, Ivanec, trade, self-management economy, consumer society, everyday life, Americanization, "Ivanečki magazin" Trading Company.

Ključne riječi: samoposluga, Jugoslavija, Ivanec, trgovina, samoupravno gospodarstvo, potrošačko društvo, svakodnevica, amerikanizacija, Trgovačko poduzeće „Ivanečki magazin“.

HR-10000 Zagreb, Meštrovićev trg 8 zrinka.miljan@gmail.com

Josip Mihaljević Hrvatski institut za povijest HR-10000 Zagreb, Opatička 10 josip@isp.hr 


\section{FILOZOFSKI FAKULTET SVEUČILIŠTA U ZAGREBU \\ ZAVOD ZA HRVATSKU POVIJEST \\ INSTITUTE OF CROATIAN HISTORY \\ INSTITUT FÜR KROATISCHE GESCHICHTE}

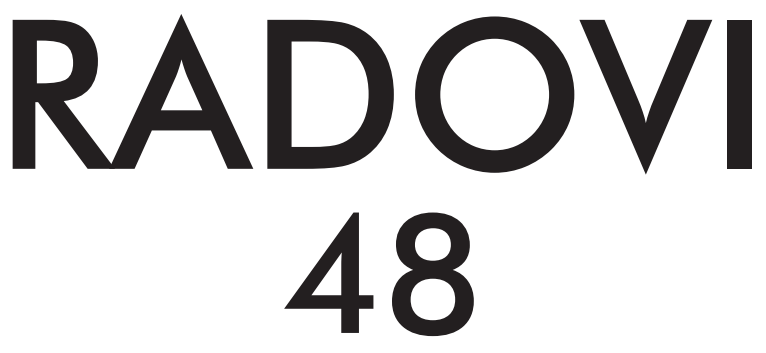

ZAVOD ZA HRVATSKU POVIJEST

FILOZOFSKOGA FAKULTETA SVEUČILIŠTA U ZAGREBU

\section{FF press}

ZAGREB 2016. 


\title{
RADOVI ZAVODA ZA HRVATSKU POVIJEST FILOZOFSKOGA FAKULTETA SVEUČILIŠTA U ZAGREBU \\ Knjiga 48
}

\author{
Izdavač / Publisher \\ Zavod za hrvatsku povijest \\ Filozofskoga fakulteta Sveučilišta u Zagrebu \\ FF-press \\ Za izdavača / For Publisher \\ Željko Holjevac \\ Glavni urednik / Editor-in-Chief \\ Hrvoje Gračanin \\ Izvršna urednica / Executive Editor \\ Inga Vilogorac Brčić \\ Uredništvo / Editorial Board
}

Bruna Kuntić-Makvić (stara povijest/ancient history), Zrinka Nikolić Jakus (srednji vijek/ medieval history), Hrvoje Petrić (rani novi vijek/early modern history), Željko Holjevac (moderna povijest/modern history), Tvrtko Jakovina (suvremena povijest/contemporary history),

Silvija Pisk (mikrohistorija i zavičajna povijest/microhistory and local history),

Zrinka Blažević (teorija i metodologija povijesti/theory and methodology of history)

Međunarodno uredničko vijeće / International Editorial Council

Denis Alimov (Sankt Peterburg), Živko Andrijašević (Nikšić), Csaba Békés (Budapest), Rajko Bratož (Ljubljana), Snježana Buzov (Columbus, Ohio), Svetlozar Eldarov (Sofija), Toni Filiposki (Skopje), Aleksandar Fotić (Beograd), Vladan Gavrilović (Novi Sad), Alojz Ivanišević (Wien),

Egidio Ivetić (Padova), Husnija Kamberović (Sarajevo), Karl Kaser (Graz),

Irina Ognyanova (Sofija), Géza Pálffy (Budapest), Ioan-Aurel Pop (Cluj),

Nade Proeva (Skopje), Alexios Savvides (Kalamata), Vlada Stanković (Beograd), Ludwig Steindorff (Kiel), Peter Štih (Ljubljana)

\section{Izvršna urednica za tuzemnu i inozemnu razmjenu / Executive Editor for Publications Exchange \\ Kristina Milković}

Tajnik uredništva / Editorial Board Assistant
Dejan Zadro

Adresa uredništva/Editorial Board address

Zavod za hrvatsku povijest, Filozofski fakultet Zagreb, Ivana Lučića 3, HR-10 000, Zagreb

Tel. ++385 (0)1 6120 150, 6120 158, faks ++385 (0)1 6156879

Časopis izlazi jedanput godišnje / The Journal is published once a year

Časopis je u digitalnom obliku dostupan na / The Journal in digital form is accessible at Portal znanstvenih časopisa Republike Hrvatske „Hrčak“ http://hrcak.srce.hr/radovi-zhp

Financijska potpora za tisak časopisa / The Journal is published with the support by

Ministarstvo znanosti, obrazovanja i športa Republike Hrvatske

Časopis je indeksiran u sljedećim bazama / The Journal is indexed in the following databases:

Directory of Open Access Journals, EBSCO, SCOPUS, ERIH PLUS, Emerging Sources Citation Index - Web of Science 


\section{Naslovna stranica}

Iva Mandić

Grafičko oblikovanje i računalni slog

Marko Maraković

\section{Lektura}

Samanta Paronić (hrvatski / Croatian)

Dražen Nemet (engleski / English)

Tisak

Tiskara Zelina d.d., Sveti Ivan Zelina

Naklada

250 primjeraka

Časopis je u digitalnom obliku dostupan na Portalu znanstvenih časopisa Republike Hrvatske ,Hrčak" http://hrcak.srce.hr/radovi-zhp

The Journal is accessible in digital form at the Hrcak - Portal of scientific journals of Croatia http://hrcak.srce.hr/radovi-zhp 


\section{RADOVI 48}

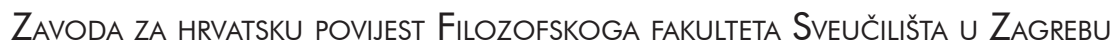

